\title{
The intimate labour of internationalism: maternalist humanitarians and the mid-twentieth century family planning movement
}

\author{
Nicole C. Bourbonnais ${ }^{\dagger}($ i) \\ International History and Politics, Graduate Institute of International and Development Studies (IHEID), Geneva, \\ Switzerland \\ E-mail: nicole.bourbonnais@graduateinstitute.ch
}

\begin{abstract}
This article moves past high politics and the most prominent activists to explore the daily, intimate practice of international movement building by mid-level fieldworkers within the International Planned Parenthood Federation (IPPF) during its first decade of existence (1952-62). It illustrates how fieldworkers and the IPPF's practitioner-oriented newsletter Around the World attempted to bridge the ideological and geographic diversity of the family planning movement and connect with advocates around the world through an emotive narrative of suffering, love, and global humanity, reinforced by affective bonds and women's volunteerism. The story of global family planning must thus be seen not only as part of the history of eugenics, population control, and feminism, but also as part of the longer trajectory of maternalist humanitarianism. This mid-twentieth century version of maternalist humanitarianism built on earlier traditions but also incorporated concepts of human rights, critiques of dominant gender and sexual norms, and an official commitment to local self-determination in the context of decolonization movements. Still, the organization was plagued by the problems that shape humanitarianism more broadly, including the difficulty of moving past colonialist discourses, deeply rooted feelings of racial superiority, and the contradictions inherent in attempts to impose an impossible ideal of political neutrality in a politically complex world. Looking at the history of global family planning from this perspective thus helps us understand how the different traditions, intimate relationships, and practical experiences mid-level actors bring to their work shape the broader process of international movement building, beyond high-level political and ideological activism.
\end{abstract}

Keywords: Family planning; population control; global health; international history; women's history

\section{Introduction}

In the two decades following the Second World War, the cause of family planning - the idea of conscientiously timing childbirth - moved from a decentralized, somewhat fringe project to become a mainstream and powerful global movement. Local family planning activists and associations around the world joined together into lasting international organizations; foreign aid agencies and donors placed family planning at the core of development agendas; governments across Africa, Asia, and the Caribbean launched state programs to distribute family planning

${ }^{\dagger}$ I would like to express my sincere thanks to the anonymous peer reviewers of this article, to my colleague Amalia Ribi Forclaz, and to Heidi Tworek, for their very helpful comments on earlier versions of this article. The article was also shaped by comments from audience members at talks given to the Global Health Seminar Series at the Graduate Institute, the Department of History Research Colloquium at the University of Basel, and the Action sociale et régulation de la famille (XIXe-XXIe siècles): Journée d'études at the Institut national d'études démographiques (INED).

(C) The Author(s), 2021. Published by Cambridge University Press. This is an Open Access article, distributed under the terms of the Creative Commons Attribution licence (http://creativecommons.org/licenses/by/4.0/), which permits unrestricted re-use, distribution and reproduction, provided the original article is properly cited. 
propaganda and contraceptives en masse. By the mid-1960s, family planning had become a multimillion-dollar international aid industry. ${ }^{1}$ This rapid ascent is all the more remarkable considering the deeply fraught politics surrounding efforts to promote family planning. The cause had roots in radical feminist and sex reform movements calling for women's control over their bodies, racist eugenic projects aimed at controlling the reproduction of those deemed 'unfit,' and neoMalthusian panic over rising population growth rates. These projects both conflicted and intersected with one another in complex ways. Following the Second World War, family planning became further entangled in Cold War and decolonization politics, seen as either the key to post-colonial development and a vital means to prevent over population, conflict, and the spread of communism, or as a capitalist/neocolonial distraction from the root causes of global inequality. The cause also faced the powerful opposition of the Catholic Church, heightening tensions between Catholic and non-Catholic countries at the United Nations. As family planning developed into 'a biological solution to a geopolitical problem,' women's reproductive bodies became the grounds on which some of the most heated battles of the twentieth century took place. ${ }^{2}$

Looking more closely at this phenomenon thus allows us to think about a larger question animating global history: how are international movements built, consolidated, and held together, in light of these political and ideological tensions? Recent transnational histories of population and family planning have pointed to the foundational activism of prominent feminists such as American advocate Margaret Sanger, as well as the allegiances they formed with an AngloAmerican network of population thinkers and the broader eugenics movement in the interwar years. ${ }^{3}$ Matthew Connelly focuses on those at the helm of post-Second World War aid agencies and international organizations, stressing the role of male philanthropists, state officials, and population experts in making the 'problem of population' a central concern on the global stage. Connelly argues that during the 1950s and 1960s, the radical early movement consolidated into a 'diversified but single-minded population establishment' led primarily by men who 'looked at human beings not as individuals but as a population that could be shaped through the combined force of faith and science. ${ }^{4}$ Family planning became the solution to development and global security challenges, incorporated into population programs managed by states and international organizations focused primarily on reducing the fertility rates of women of colour around the world. ${ }^{5}$

These studies have illustrated the often racist, sexist, and Western-centric roots of the family planning movement and how the cause gained currency in the upper echelons of national and global governance. But the family planning movement did not operate solely on the level of high politics or in the world of male expertise; this was an intimate international project, made in

\footnotetext{
${ }^{1}$ Matthew Connelly, Fatal Misconception: The Struggle to Control World Population (Cambridge, MA: The Belknap Press of Harvard University Press, 2008), 233.

${ }^{2}$ Alison Bashford, Global Population: History, Geopolitics and Life on Earth (New York: Columbia University Press, 2014), 305. For broad overviews, see Connelly, Fatal Misconception, Betsy Hartmann, Reproductive Rights and Wrongs: The Global Politics of Population Control (South End Press, 1995), Faye D. Ginsburg and Rayna Rapp, eds. Conceiving the New World Order: The Global Politics of Reproduction (University of California Press, 1995), Manon Parry, Broadcasting Birth Control: Mass Media and Family Planning (New Brunswick: Rutgers University Press, 2013), and Rickie Solinger and Mie Nakachi, ed. Reproductive States: Global Perspectives on the Invention and Implementation of Population Policy (Oxford: Oxford University Press, 2016).

${ }^{3}$ Bashford, Global Population, Aiko Takeuchi-Demirci, Contraceptive Diplomacy: Reproductive Politics and Imperial Ambitions in the United States and Japan (Stanford: Stanford University Press, 2018), Jonathan Zimmerman, Too Hot to Handle: A Global History of Sex Education (Princeton and Oxford: Princeton University Press, 2015), Alison Bashford and Philippa Levine, eds. The Oxford Handbook of the History of Eugenics (Oxford: Oxford University Press, 2010). For more on the role of Sanger and connections with neo-Malthusianism/eugenics within the American context, see Linda Gordon, The Moral Property of Women: A History of Birth Control Politics in America (Chicago: University of Illinois Press, 2002) and Dorothy Roberts, Killing the Black Body: Race, Reproduction, and the Meaning of Liberty (New York: Pantheon Books, 1997).

${ }^{4}$ Connelly, Fatal Misconception, 17, xii.

${ }^{5}$ Ibid, xii.
} 
bedrooms as much as boardrooms. It required the active engagement of a much broader range of actors, including thousands of doctors, nurses, social workers, and field workers who served as the 'hands and faces of the movement': opening clinics, hanging family planning posters, visiting mothers in their homes, inserting intra-uterine devices (IUDs), and running contraceptive research trials. ${ }^{6}$ Local studies have highlighted the importance of these actors in shaping how the movement played out in practice, from South Africa to Jamaica to Peru. ${ }^{7}$ And yet, global histories have rarely considered how international organizations attempted to engage with these advocate practitioners - involved not only in talking about, but actually doing the work of family planning - in their efforts to spread the cause around the world. ${ }^{8}$ In our fascination with the heated global geopolitics of family planning, we have perhaps lost sight of the daily practice of international activism, and the more intimate tensions that might play out among the broader range of actors who built and consolidated the family planning movement in the mid-twentieth century.

This paper seeks to shift our attention by exploring the early years of the International Planned Parenthood Federation (IPPF), an organization created in 1952 with the aim of supporting and encouraging the work of local Family Planning Associations (FPAs) around the world. I begin by situating the emergence of the IPPF within the broader history of family planning, highlighting the organization's diverse ideological roots and unique federation structure. I then focus on the archives of American advocate Dorothy Hamilton Brush, a fieldworker for the IPPF and the first editor of its newsletter, Around the World: News of Population and Birth Control. Brush's rich personal collection includes accounts from other IPPF fieldworkers, reports by local FPAs of their work, and personal correspondence with doctors, nurses, and other family planning practitioners from across six continents. The collection also includes a bound ten-year run (1952-62) of Around the World, including 107 volumes ranging from 4 to 8 pages each, edited by Brush from 1952-56 and British doctor L.N. Jackson from 1956-62. ${ }^{9}$ The newsletter specifically targeted local family planning advocate practitioners, seeking to support their work, bring them into conversation with one another, and create a sense of a shared mission across borders. It was, as IPPF president Margaret Sanger described: 'the glue which holds our far-flung workers together.' ${ }^{10}$ The newsletter is thus a particularly rich source for examining how mid-level actors built an international movement at a critical historical juncture in the rise of the global family planning movement.

Looking at the movement from this position draws our attention to the somewhat different logics operating amongst the movement's 'workers.' I argue that the mid-twentieth century global

\footnotetext{
${ }^{6}$ Raul Necochea López, 'Gambling on the Protestants: The Pathfinder Fund and Birth Control in Peru, 1958-1965’, Bulletin of the History of Medicine 88, no. 2 (2014): 371.

${ }^{7}$ See for example Laura Briggs, Reproducing Empire: Race, Sex, Science, and U.S. Imperialism in Puerto Rico (University of California Press, 2003), Amy Kaler, Running After Pills: Politics, Gender, and Contraception in Colonial Zimbabwe (Portsmouth: Heinemann, 2003), Susanne Klausen, Race, Maternity, and the Politics of Birth Control in South Africa, 1910-39 (Basingstoke, Hampshire and New York: Palgrave Macmillan, 2004), Sanjam Ahluwalia, Reproductive Restraints: Birth Control in India, 1877-1947 (Urbana and Chicago: University of Illinois Press, 2008), Raúl Necochea López, A History of Family Planning in Twentieth-Century Peru (Chapel Hill: University of North Carolina Press, 2014), and Nicole Bourbonnais, Birth Control in the Decolonizing Caribbean: Reproductive Politics and Practices on Four Islands, 1930-1970 (New York: Cambridge University Press, 2016). See also Michelle Murphy, 'Technology, governmentality, and population control', History and Technology, 26, no. 1 (March 2010): 70 for this point.

${ }^{8}$ Exceptions include Necochea López, 'Gambling on the Protestants', Caroline Rusterholz, 'English Doctors, Contraception and Family Planning in International Perspective (1930s-70s)', Medical History 63, no. 2 (2019): 153-72, and Nicole Bourbonnais, 'Population Control, Family Planning, and Maternal Health Networks in the 1960s/70s: Diary of an International Consultant', Bulletin of the History of Medicine 93, no. 3 (Fall 2019): 335-64.

${ }^{9}$ The paper continued afterwards under the new moniker of International Planned Parenthood News from 1964-1975 and under various names afterwards, but these are not held in Brush's collection and I was unable to access other archives due to the ongoing Covid-19 pandemic.

${ }^{10}$ 'Farewell', Around the World (hereafter ATW), vol. 50, 1956/12, (B6, Dorothy Hamilton Brush Papers, Sophia Smith Collection, Smith College, Northampton, Massachusetts. Hereafter 'DHB Papers, SSC.'), 4.
} 
family planning movement needs to be situated not only within the history of feminism, eugenics, and population control, but also as part of the history of maternalist humanitarianism: a version of humanitarianism rooted in an appeal to ethics and emotion with women's labour, family wellbeing, and maternal suffering at its core. ${ }^{11}$ Fieldworkers such as Brush and her local correspondents portrayed themselves as united above all by their shared experiences as witnesses to maternal suffering. They placed the question of family health and well-being on nearly the same par as population concerns and mobilized an emotional language of compassion and empathy that contrasts sharply with the dehumanizing language of population control. They also continued to portray the movement as primarily rooted in women's labour and leadership. In Brush's papers, we thus see a movement held together less by single-minded ideological unity and more by the construction of an 'emotional community,' sharing a common affective language and reinforced by the daily labour of newsletter writing, personal correspondence, exchanges of gifts, and volunteer work by women. ${ }^{12}$

If family planning 'workers' shared more in common with maternalist humanitarians than the male population 'experts' encroaching in other levels and spaces of the movement, these advocates also departed from more traditional maternalist humanitarians in important ways. For one, the language of suffering was mixed with a language of human rights - including children's rights and women's rights - increasingly present on the international stage. The ATW newsletter also gave space to somewhat risqué discussions of sex and critiques of gender relations that challenged more conservative visions of motherhood and the family. As illustrated in the final section of this article, $A T W$ further attempted to respond to the mid-century context of decolonization, presenting a narrative of global family planning struggle in which Asian countries assumed leadership, Western countries came to international spaces to learn, and organizations such as the IPPF were responsive to demands for self-determination among local activists. Still, Brush's papers illustrate how colonial mentalities and ideologies of racial superiority continued to seep through the work of IPPF organizers: the racism of the movement was not only evident in the discourse of population controllers, but was also an intimate practice among these intermediary actors. The humanitarian ideal of political neutrality embraced by the IPPF also ultimately proved destructive in practice, as the work of the IPPF was seen as complicit with coercive state policies that received widespread condemnation from the 1970s onwards.

Delving into the daily work of community building and situating the story of global family planning within the historiography of maternalist humanitarianism thus allows us to see how the different traditions, intimate relationships, and practical experiences mid-level actors bring to their work shape the broader process of international movement building, while also illustrating how they confront the contradictions of the movement in practice. It provides us with a view of the mid-century global family planning movement as a project more female, intimate, and aware of critique than it might have appeared at population conferences, but also riddled with deeper frictions that may prove harder to overturn in the long run. Indeed, while the population control agenda has faced a significant challenge in the international arena following the rise of the reproductive rights paradigm in the $1990 \mathrm{~s},{ }^{13}$ most of the tensions outlined below continue to shape the project of family planning and humanitarianism more broadly. As a result, I argue, it is critical to contend with the assumptions and implications of family planning done not only in the name of

\footnotetext{
${ }^{11}$ Here I am fusing definitions of humanitarianism from Matthew Hilton, et al., 'History and Humanitarianism: A Conversation', Past \& Present, 241, no. 1 (November 2018): 17-8 with definitions of maternalism in Rebecca Jo Plant and Marian van de Klein, 'Introduction: A New Generation of Scholars on Maternalism', 1-21 in Marian van der Klein, et al. eds, Maternalism Reconsidered: Motherhood, Welfare and Social Policy in the Twentieth Century (New York: Berghahn Books, 2012).

${ }^{12}$ For the concept of an 'emotional community', see: Ilaria Scaglia, The Emotions of Internationalism: Feeling International Cooperation in the Alps in the Interwar Period (Oxford University Press, 2019).

${ }^{13}$ Connelly, Fatal Misconception, 327-69.
} 
global security, but also in the name of love and suffering, recognizing the critical role of daily intimate labour in the construction - and destruction - of international bonds.

\section{From birth control to planned parenthood: The emergence of the IPPF}

The creation of the IPPF was built on a longer tradition of birth control activism dating back to the late nineteenth century. The basic idea of limiting reproduction, of course, was not new: historians have found evidence of rudimentary methods used to prevent pregnancies across societies, dating as far back as the Roman Empire. The vulcanization of rubber in the 1850s allowed for the production of more reliable methods such as the condom and the female diaphragm, and manufacturers developed a range of spermicidal foams, powders, and gels sold at pharmacies in the early twentieth century. Laws, taboos, and lack of education and health services, however, limited the reach of these methods. Local campaigns arising in the late nineteenth and early twentieth centuries thus focused on spreading awareness of and access to contraception by publishing pamphlets, establishing clinics to distribute diaphragms and other methods, and lobbying governments to include birth control services within public health programs. By 1930, birth control organizations existed in at least thirty countries around the world, operated by a mix of sex reform, feminist, eugenicist, and neo-Malthusian associations. ${ }^{14}$ Advocates also worked from the outset to build international connections. The London-based 'Birth Control International Information Centre' (BCIIC) was created in 1935 to serve as a hub for these activities, providing practical guidance to local clinics around the world and organizing international lecture tours. From 1935-36, for example, American activist Margaret Sanger and British activist Edith How-Martyn visited India, Burma, Malay, China, the Philippines, Japan, Hawaii, and Canada on a BCIIC 'World Tour.'15

These activities were disrupted by the outbreak of the Second World War, with clinics in several countries closing their doors or struggling to maintain supplies. The birth control movement was also undermined by its longstanding ties to eugenics, a movement under increasing critique due to its association with the dramatic euthanasia and coerced sterilization policies of the Nazi regime. ${ }^{16}$ With the end of the war, however, activists moved to revitalize international networks under the new rubric of 'family planning' or 'planned parenthood.' The Swedish Society for Sexuality Education (RFSU), headed by Elise Ottesen-Jensen, organized a first conference in 1946 attended by advocates from Europe and the USA, who met again in 1948 in England and formed the International Planned Parenthood Committee (IPPC) with headquarters at the FPA of England. The IPPC began to establish contact with old and new associations around the world, culminating in a widely attended conference in Bombay in 1952. India had just launched the world's first state-funded family planning program that year, making it the perfect site to consolidate networks and launch a more permanent international federation. ${ }^{17}$ The creation of the IPPF was announced at the end of the conference, with associations from England, Netherlands, Hong Kong, India, Singapore, Sweden, the United States, and West Germany as its eight founding members. The IPPF's constitution outlined its central goals: to bring about acceptance of 'voluntary responsible parenthood,' to assist in the formation of Family Planning Associations (FPAs) around the world, to stimulate and disseminate scientific research, to provide training and support quality standards in contraceptives, and to organize international conferences. Any national FPA could apply for full membership in the federation with

\footnotetext{
${ }^{14}$ Klausen, Race, Maternity, and the Politics of Birth Control in South Africa, 9; Gordon The Moral Property of Women, 7-22.

${ }^{15}$ Ahluwalia, Reproductive Restraints, 54-81.

${ }^{16}$ Connelly, Fatal Misconception, 80.

${ }^{17}$ On the Indian movement, see Ahluwalia, Reproductive Restraints and Sanjam Ahluwalia and Daksha Pamar, 'From Gandhi to Gandhi: Contraceptive Technologies and Sexual Politics in Postcolonial India, 1947-1977', in Solinger and Nakachi, Reproductive States, 124-55.
} 
representation on the Governing Council, while organizations not national in scope could apply for associate membership. ${ }^{18}$

The IPPF was one of several organizations formed after the war with planned parenthood, population, or some combination of the two in its mandate. Indeed, Connelly's Fatal Misconception situates the IPPF as one element of the emerging, male-dominated mid-century 'population establishment,' consisting of the IPPF, the Population Council (1952), the Pathfinder Fund (1957), the United Nations Fund for Population Activities (UNFPA) (1969), and the United States Agency for International Development (USAID)'s Office of Population (1969). ${ }^{19}$ Key IPPF founders such as British eugenicist C.P. Blacker clearly saw 'planned parenthood' as an extension of population control activism - with eugenic undertones - under a new, more palatable moniker. ${ }^{20}$ The IPPF's first president, Margaret Sanger, had also strayed far from her socialist feminist roots by this point, actively mobilizing eugenic and neo-Malthusian arguments and courting male population experts to rally support for the cause. ${ }^{21}$ As Connelly argues, the growth of the movement in the post-war period was achieved 'through a series of political compromises, culminating with the consolidation of a well-funded and well-connected establishment committed to the most conservative version of family planning. ${ }^{22}$

While these statements certainly hold true at some levels, the IPPF - and the family planning movement more broadly - cannot be reduced to the perspectives of its most prominent advocates. Several IPPF board members, such as Ottesen-Jensen, continued to bring more radical, rightsbased, and/or individualist understandings of planned parenthood to the table. As Vicky Claeys points out, the very selection of 'planned parenthood' in the federation's name reflected a concerted effort by Dutch and Swedish activists not to have the movement dominated by the 'American' interest in population problems (Sanger had preferred 'The International Population Planning Committee'). ${ }^{23}$ Caroline Rusterholz's recent scholarship further illustrates how British doctors such as Helena Wright, Cecily Mure, and Margaret Jackson continued to incorporate feminist principles into their work for the organization. While their efforts often went unrecognized, these women played a crucial role in the movement, promoting family planning through lecture tours, while also conducting research trials of new spermicidal methods, IUDs, and the birth control pill in the late $1950 \mathrm{~s}^{24}$

The IPPF was also unique from other organizations at the time due to its federation structure. Although the Governing Council - made up of representatives from local associations - outlined standards and provided small grants, publications, contraceptives and materials, the IPPF itself did not open or run clinics abroad. The day-to-day work of the movement thus continued to be undertaken by local FPAs run by local doctors, nurses, social workers, and volunteers, who brought their own diverse interests to the cause. ${ }^{25}$ Often, it was these associations that took the initiative to reach out to the IPPF. In its Fourth Report for the years 1957-58, for example, the IPPF noted that it had responded to some 3,494 letters of inquiry from 89 countries, hosted 170 visitors from 48 countries at its London headquarters, and provided training for 78 doctors

\footnotetext{
${ }^{18}$ 'World Foundation', ATW, vol. 18, 1953/10, (B6, DHB Papers, SSC), 1. Vicky Claeys, 'Brave and angry - The creation and development of the International Planned Parenthood Federation (IPPF)', The European Journal of Contraception \& Reproductive Health Care 15, sup 2 (2010): 67-76.

${ }^{19}$ Connelly, Fatal Misconception, 17.

${ }^{20}$ Ibid, p105-107, 163.

${ }^{21}$ Gordon, The Moral Property of Women, 282, Parry, Broadcasting Birth Control, 79, Takeuchi-Demirci, Contraceptive Diplomacy, 13, 15.

${ }^{22}$ Connelly, Fatal Misconception, p266.

${ }^{23}$ Claeys, 'Brave and angry', 69; Rusterholz, 'English Doctors, Contraception and Family Planning', 158.

${ }^{24}$ Rusterholz, 'English Doctors, Contraception and Family Planning', 153-72.

${ }^{25}$ Sandra Whitworth, Feminism and International Relations: Towards a Political Economy of Gender in Interstate and Non-Governmental Institutions (St. Martin's Press 1994), 90-92.
} 
and 34 nurses. ${ }^{26}$ Membership in the IPPF grew from its original eight members in 1952 to 34 members by 1963 (see Figure 1), and the organization opened five regional offices to serve Europe, the Near East, and Africa; the Indian Ocean; South East Asia and Oceania; the Western Hemisphere; and the Western Pacific. ${ }^{27}$ As the organization's monthly Around the World $(A T W)$ newsletter noted, in the first decade of its existence the IPPF had developed from a 'fledgling organization' to a 'world-wide force. ${ }^{28}$

IPPF Country Membership 1963

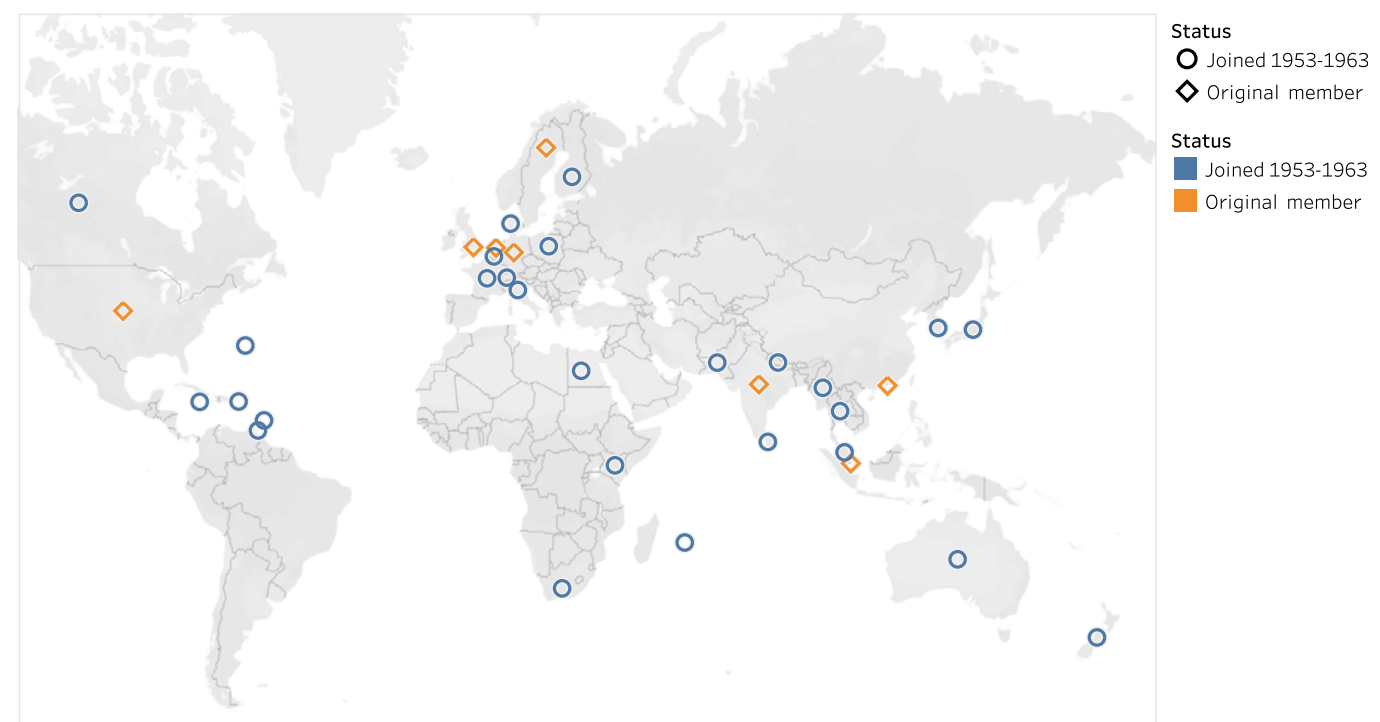

() 2021 Mapbox @ OpenStreetMap

Figure 1. IPPF Country Membership 1963.

One of the fundamental goals of the IPPF was to try and bring this diverse network of actors together under a common rubric, to provide some sense of shared mission and unity across geographical and ideological diversity. To this end, Sanger saw the creation of the ATW newsletter as a crucial initiative. As she noted, the primary intended audience for the paper were people 'already interested in BC [birth control] who like to know what is going on elsewhere. ${ }^{29}$ The paper would serve as a medium to exchange news and practical strategies, while also providing 'workers' with 'the encouraging assurance that they are not struggling alone. ${ }^{30}$ Sanger argued that the format of a four page newsletter - 'small and compact and newsy' - was ideal for busy workers, cheap to mail out, and relatively easy to translate into foreign languages (see Figure 2 ). ${ }^{31}$ The paper started in January 1952 and was initially provided free for all, although from September 1952 onwards American and Canadian readers were charged a $\$ 2$ annual subscription to fund foreign

\footnotetext{
${ }^{26}$ IPPF, 'Fourth Report', London, England, 1957/01/01-1959/05/31. (B6, DHB Papers, SSC), 14.

${ }^{27}$ IPPF, 'Sixth Report', London, England, 1963. (B6, DHB Papers, SSC).

${ }^{28}$ L.N.J., 'Dorothy Brush', ATW, vol. 96, 1961/06, (B7, DHB Papers, SSC), 3.

${ }^{29}$ Margaret Sanger to T.O. Griessemer, 'Letter', 1955/01/06. (F27, B1, DHB Papers, SSC), 1-2.

${ }^{30}$ Margaret Sanger, 'Happy Birthday', ATW, vol. 21, 1954/01, (B6, DHB Papers, SSC), 1.

${ }^{31}$ Margaret Sanger to T.O. Griessemer, 'Letter', 1955/01/06. (F27, B1, DHB Papers, SSC), 1-2.
} 


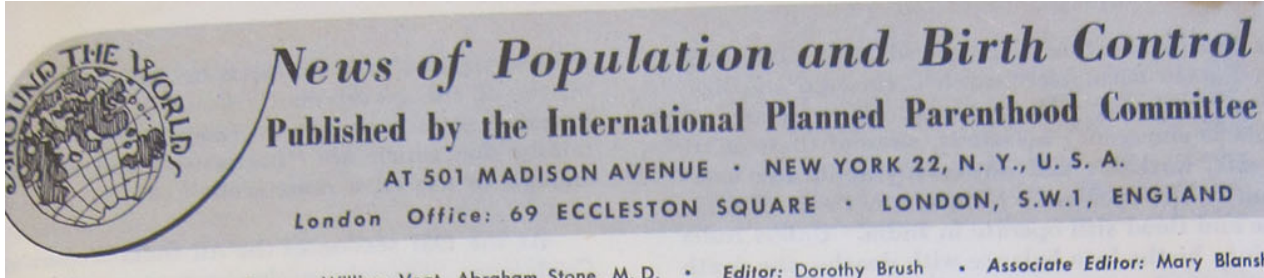

dvisory Council: Margaret Sanger, William Vogt, Abraham Stone, M. D.

Editor: Dorothy Brush

January, 1952

No. 1

\section{TO OUR FRIENDS:}

This is a most significant hour, important to our civilization, vital to unborn generations. One of the leading goals of our movement, a controlled population, is in sight. The International Planned Parenthood Committee is bombarded with requests for films, literature, supplies, information----everything to aid groups and individuals to organize educational campaigns to spur official action and raise funds for birth control centers. These voluntary groups are eager to pioneer, to enlighten their own citizens in the techniques of spacing pregnancies and controlling birth rates. They need help, encouragement, the assurance that they are not struggling in isolation. To that end we offer this modest monthly report. We want your cooperation, support, and news of activities everywhere.

Margaret Sanger

INTERNATIONAL P. P. COMMITTEE

Two international conferences on population and planned parenthood have been held since World War II: in Stockholm, Sweden (1946) and in Cheltenham, England (1948). Following the Cheltenham Congress, the International Committee on Planned Parenthood was organized with representatives from England, Holland, Sweden and the United States. The latest meeting was held in London in 1951. Lady Rama Rau, President of the Family Planning Association of India, invited the Committee to hold the next conference late in 1952 in India; to facilitate attendance for Far Eastern countries.

Visitors to London Headquarters during 1951 came from Austria, Burma, Canada, Germany, Hong Kong, India, Indonesia, Jamaica, Japan, Malaya, Mauritius, Pakistan, Singapore, Switzerland, Tonga (South Pacific), Turkey, Union of South Africa, the United States.
Requests for services were received from Africa (Gold Coast, Kenya, Nigeria, Nyasaland, North Rhodesia, South Rhodesia, Sierra Leone, Tanganyika, Uganda, Union of South Africa), Australia, Belgium, Canada, Ceylon, Cyprus, Egypt, France, Germany, Greece, British Guiana, Holland, Hong Kong, India, Iran, Iraq, Italy, Malaya, Malta, New Zealand, Norway, Pakistan, Portugal, Persian Gulf, St. Helena, Singapore, Tonga (South Pacific), Trieste, Turkey.

Because of such world-wide interest, the I. P. P. C. in London requested the American members to initiate this news report. Funds were made available by the Brush Foundation, Cleveland, Ohio. We wish to thank Mrs. Walter Flory of Cleveland for designing the globe on our masthead.

\section{THE WORLD'S POPULATION}

From the United Nations comes a report that the population of the world was approximately 2 billion, 400 million in mid-1950. According to information released by the Statistical Office of the United Nations, populations by continents were: Africa, 198,000,000; North America, 216,300,000; South America, 111,400,000; Asia (excluding the Soviet Union) 1,272,000,000; Europe (excluding the Soviet Union) 396,000,000; Oceania, 12,900,000; Soviet Union, 193,000,000 (1946 total).

World numbers are increasing by at least 25 million yearly. Net increase of births over deaths is approximately 60,000 each day, 2,500 each hour, 41 each minute. The real cause in the rate of growth is the steadily declining death rate. The only alternative to balancing numbers by more deaths is to achieve a balance through fewer births. Expedients to this end have been most varied: Ireland for over a century has achieved it by delayed marriages and a high rate of celibacy;

Be reporters of population and birth control news for us. Comment invited.

Figure 2. First issue of Around the World, January 1952. 
distribution. ${ }^{32}$ At the end of its first year, $A T W$ was reportedly reaching 6700 people each month, in about 100 countries and colonies; by its second anniversary, this number had doubled to 12,000 readers. $^{33}$ By January 1956, volunteers regularly translated the paper into German, Spanish, Japanese, Italian, and French, with occasional issues in Chinese, Flemish, and Hausa. ${ }^{34}$

The paper was edited initially by American Dorothy Hamilton Brush until 1956, when she resigned due to ill health and British doctor L.N. Jackson (husband of Dr. Margaret Jackson) took over. Both editors primarily obtained material for $A T W$ by (1) scanning newspapers, scientific journals, and other published materials for relevant news stories; (2) drawing on IPPF fieldworker reports and information provided by the organization's secretary, Vera Houghton; and (3) soliciting updates directly from local FPAs. Brush, in particular, had close relations with advocates around the world and tapped into these networks to obtain material. ${ }^{35}$ The result was a paper that featured an impressive geographical scope. Although around one-third of the articles published from 1952-62 covered broad issues relating to family planning, tracked new research and/ or documented the activities of the IPPF, feature articles covered local developments in some eighty different countries (see Figure 3). As Brush noted in correspondence, she tried to represent as many countries as possible 'to give people the needed impression that the movement is far more widespread than they think. ${ }^{36}$

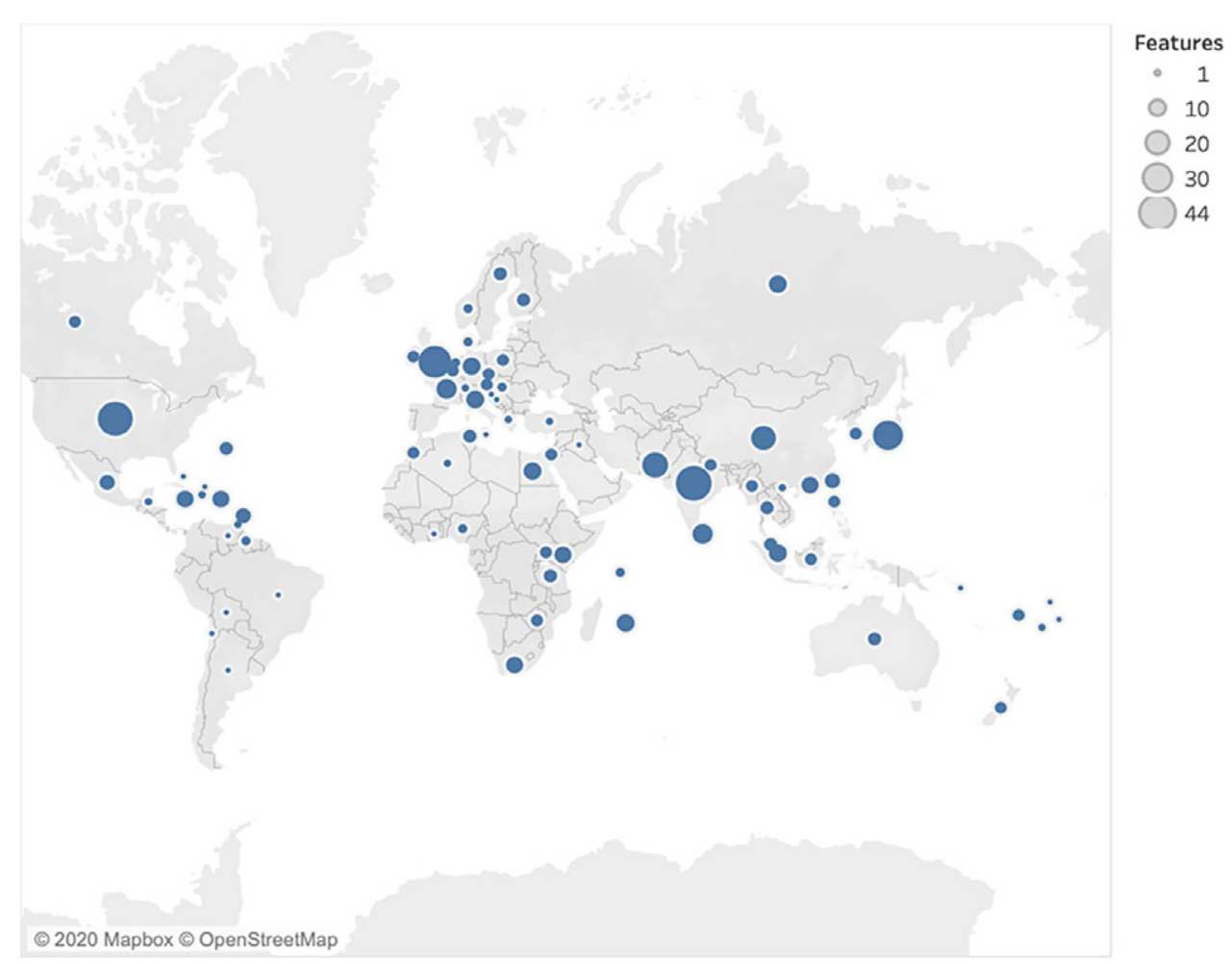

Figure 3. Countries featured in ATW coverage (1952-62).

\footnotetext{
${ }^{32}$ Notes', $A T W$, vol. 6, 1952/06, (B6, DHB Papers, SSC), 4.

${ }^{33 ‘}$ 'Our First Birthday', $A T W$, vol. 11, 1953/01, (B6, DHB Papers, SSC), 4. Margaret Sanger, 'Happy Birthday', ATW, vol. 21, 1954/01, (B6, DHB Papers, SSC), 1.

${ }^{34}$ 'IPPF Progress', ATW, vol. 41, 1956/01, (B6, DHB Papers, SSC), 4.

${ }^{35}$ [Dorothy Brush] to Maude [Jolly], 'Letter', 1960/03/31. (F5, B2, DHB Papers, SSC, 1.

${ }^{36}$ Brush to 'Mrs. Houghton', 1951/12/13. (F11, B6, DHB Papers, SSC), 2.
} 
The narrative constructed by the paper thus documented a broader set of interests and perspectives than we might see in other spaces in the same period. Coverage of United Nations population conferences and new state policies sat alongside intimate stories of local doctors, nurses, and social workers setting up small clinics and conducting outreach activities with mothers and communities. Through ATW and Brush's broader personal archives, we see a vision of the family planning movement swept up by the post-war population panic, but also rooted in the longer tradition and rhetoric of maternalist humanitarianism, merged with attention to human rights, feminist critique, and the politics of decolonization.

\section{'Soft songs of love and suffering': maternalist humanitarianism and the construction of an emotional community}

The tone of Around the World was heavily influenced by its first editor, Dorothy Hamilton Brush, and her longer trajectory/vision of the movement. Brush described her involvement in the movement as, above all, 'accidental,' driven by experiences she had as a young woman volunteering at a Roman Catholic-dominated pre-natal clinic in Cleveland, Ohio in the early 1920s. As she wrote in an autobiographical article in 1957:

Pregnant girls our own age attended - already with two, three or more children; girls with no money and terrible anxiety. 'How can I stop another baby,' they begged, 'or put it off for a few years?' We ourselves knew very little - but we told what we knew. Found out, we were dismissed! We promptly persuaded our mothers and friends to start a birth control committee. $^{37}$

Through her work with the new Maternal Health Association of Cleveland, Brush met and befriended Margaret Sanger, accompanying her on a 1937 world tour as a 'birth control missionary,' and sitting on the steering committee for the 1946 IPPC conference in Stockholm. ${ }^{38}$ Brush also conducted several trips on behalf of the organization in the 1950s, through her role as 'honorary fieldworker.' When the IPPF launched ATW in 1952, Sanger saw Brush as the perfect person to 'midwife' the organization's newest 'child' into fruition. ${ }^{39}$ Brush also arranged for an annual grant to pay the basic expenses of $A T W$ from The Brush Foundation for Race Betterment, an organization established by the Brush family in honour of Dorothy's late husband, Charles F. Brush, a physicist with eugenic leanings.

Brush's profile matched that of many IPPF fieldworkers and mid-level staff: a relatively privileged white woman with a background in maternal health and ties to eugenic and feminist movements. But the language she used to describe her engagement in the movement was also representative of a broader discourse prominent among family planning workers beyond the Anglo-American context. As evident in local-level studies and oral history collections, while eugenic, feminist, and population control discourses certainly held broad sway across the globe, many family planning advocates portrayed their work as driven primarily by an imperative to respond to suffering, rather than as part of any clear political movement or social agenda. ${ }^{40}$ Doctors, nurses, and social workers from Taiwan to Indonesia to Venezuela described themselves as having been 'shocked into action' after seeing patients struggle with health complications

\footnotetext{
${ }^{37}$ Dorothy Brush, 'Feathers in my Cap', ATW, vol. 51, 1957/01, (B7, DHB Papers, SSC), 1-2.

${ }^{38}$ Ibid, 1.

${ }^{39}$ Ibid, 2.

${ }^{40}$ See for example Klausen, Race, Maternity, and the Politics of Birth Control in South Africa, Necochea López, A History of Family Planning in Twentieth-Century Peru, Bourbonnais, Birth Control in the Decolonizing Caribbean, Bourbonnais, 'Population Control, Family Planning, and Maternal Health Networks in the 1960s/70s', and oral histories with Grace Ebun Delano Nafis Sadik, Mario Jaramillo, Fred Sai, and Sandra Kabir conducted by The Population and Reproductive Rights Oral History: http://www.smith.edu/libraries/libs/ssc/prh/prh-intro.html
} 
caused by multiple pregnancies, complicated childbirths, and self-administered abortions that had gone awry. ${ }^{41}$ Some advocates drew on experiences within their own families. As Nurse Campbell of the Jamaica Birth Control League wrote in 1943:

Unless I am dismissed I really would not give up this post. You see its [sic] not a matter of merely working for money its a post I am heart and soul with. My mother had six of us in 11 years and my father died leaving a five month old boy... Mother worked so hard to help us that she will never be well again. Do you see that if there were less of us she at least would be well and strong? ${ }^{42}$

Like Brush, many of these advocates mobilized religious metaphors, describing themselves as 'missionaries' who had been 'converted' to 'the gospel of family planning' through these experiences and their sense of duty as moral actors; others saw their work as part of their ethical responsibility as health professionals, or as a basic human response to the experience of witnessing suffering. ${ }^{43}$

With these narratives, family planning workers likened themselves to modern humanitarians, 'moved to action by their identification with the suffering of distant others. ${ }^{44}$ As scholars have noted, the history of humanitarianism has included both an 'emergency branch' focused on keeping people alive in times of crisis (such as the Red Cross and Doctors Without Borders) as well as organizations that developed broader poverty eradication and development programs aimed at addressing the root causes of suffering, such as Save the Children and Care International. ${ }^{45}$ What unites these different initiatives is the embrace of an ethical imperative to act driven by an emotional response, drawing on narratives of sympathy and empathy over ideological or political rationales. For humanitarians, the relief of suffering is portrayed as an end in itself, rather than a means to achieve a larger social agenda. ${ }^{46}$ Indeed, many humanitarians portray their work as essentially 'apolitical' and embrace an ideal of political neutrality as a fundamental operating principle. ${ }^{47}$ Similar to missionaries, humanitarians often share a sense of 'transcendental significance,' seeing their work as a 'calling' and part of a broader effort to construct a caring international community shaped by 'common humanity.' 48

As recent scholarship has stressed, women have historically featured heavily in humanitarian activism, not only as suffering victims and targets of humanitarian action, but also as humanitarians themselves. In addition to well-known humanitarians such as Josephine Butler and Florence Nightingale, female aid workers, nurses, social workers, and doctors served on the frontlines and formed the backbone of many twentieth-century humanitarian organizations. Female volunteers also did much of the unpaid work of these movements, knitting blankets for orphaned children, putting together supply packages for refugees, and leading fundraising activities. ${ }^{49}$ Many of these women found their entry into the field through a narrative of maternal responsibility,

\footnotetext{
${ }^{41}$ Bourbonnais, 'Population Control, Family Planning, and Maternal Health Networks', 345.

${ }^{42}$ Quoted in Bourbonnais, Birth Control in the Decolonizing Caribbean, 114.

${ }^{43}$ Bourbonnais, 'Population Control, Family Planning, and Maternal Health Networks', 344-7.

${ }^{44}$ Esther Möller, et al., 'Gendering Twentieth Century Humanitarianism', 1-34 in Esther Möller, et al. eds. Gendering Global Humanitarianism in the Twentieth Century: Practice, Politics and the Power of Representation (Palgrave Macmillan, 2020 ), 5.

${ }^{45}$ Michael Barnett, Empire of Humanity: A History of Humanitarianism (Ithaca and London: Cornell University Press, 2011), 10; Hilton et al, 'History and Humanitarianism', e1.

${ }^{46}$ See Hilton, et al., 'History and Humanitarianism', Richard Ashby Wilson and Richard D. Brown, 'Introduction', 1-30 in Humanitarianism and Suffering: The Mobilization of Empathy (Cambridge University Press, 2009); Laura Suski, 'Children, Suffering, and the Humanitarian Appeal', 202-22 in Wilson and Brown, eds. Humanitarianism and Suffering; Barnett, Empire of Humanity and Miriam Ticktin, 'International Humanitarianism', Annual Review of Anthropology, 43 (2014): 273-89.

${ }^{47}$ Wilson and Brown, 'Introduction', 2; Suski, 'Children, Suffering, and the Humanitarian Appeal', 210.

${ }^{48}$ Barnett, Empire of Humanity, 21, 37, 102.

${ }^{49}$ Moller et al., 'Gendering Twentieth Century Humanitarianism'; Plant and van der Klein, 'Introduction', 1-21.
} 
portraying themselves as the natural caretakers of victimized women and children, and appealing to feminized emotions of sympathy and maternal instinct. They also frequently concentrated their work in the fields of maternal and child health and welfare: opening maternity clinics, advocating for child welfare, facilitating child rehabilitation and adoption, distributing milk, and providing for poor mothers. In doing so, scholars have argued, they adopted a 'maternalist' approach to both emergency relief and longer-term development projects. ${ }^{50}$

In spite of the similarities evident above, historians of humanitarianism in general and maternalist humanitarianism in particular have rarely included family planning organizations within their scope. This may reflect the fact that some humanitarian organizations in the twentieth century distanced themselves in the international arena from the global family planning movement out of fear that such a divisive subject could harm their cause. ${ }^{51}$ The links between maternalist narratives and family planning have been recognized by some scholars of the family planning movement, particularly when focusing on the interwar period. Sarah Hodges, for example, traces how early South Indian birth control advocates embraced a 'maternalist biopolitics,' and Aiko Takeuchi-Demirci argues that Sanger and her Japanese counterpart, Ishimoto Shidzue, mobilized a narrative of 'maternalist pacifism and liberal internationalism' in the $1920-40 \mathrm{~s}^{52}$ This language of maternalism, however, has been tied to biopolitics, pacifism, and liberal internationalism, rather than the specific frame of international humanitarianism with its emphasis on emotion, ethics, and (the impossible ideal of) political neutrality. Scholars of the family planning movement have also largely agreed that any focus on women and maternal suffering was displaced after the Second World War by the widespread panic over rising population growth rates in the Global South and the emergence of the population establishment. ${ }^{53}$

The influence of the population panic is, indeed, evident in the $A T W$ newsletter. As seen in Figure 4, it was the most frequently covered subject under both Brush and Jackson's editorship. ${ }^{54}$ In the paper's first number, Brush quoted ecologist William Vogt's assertion that '[w]orld over population represents more of a threat to peace than the atom bomb' and nearly every edition of the paper included a review of a new book or report documenting the rise of world population, a testament to the sheer explosion of literature on the subject during this period. ${ }^{55}$ But coverage in ATW also focused considerably on questions of family health and wellbeing, raising this aspect almost as frequently as population. Articles discussed the financial and emotional toll of childbearing on family life and situated this as a central concern of the movement. As the director of the IPPF South East Asia region Nicholas Read-Collins argued: '[s]uccess in this work was not measurable only in terms of population figures, but also in parental satisfaction and relief from worry which was not statistically measurable. ${ }^{56}$

\footnotetext{
${ }^{50}$ On maternalism see: van der Klein, et al. eds, Maternalism Reconsidered, Molly Ladd-Taylor, 'Toward Defining Maternalism in U.S. History.' Journal of Women's History 5, no. (2), (1993): 110-3; Jean Allman, 'Making Mothers: Missionaries, Medical Officers and Women's Work in Colonial Asante, 1924-1945', History Workshop 38 (1994): 23-47; Anna Davin, 'Imperialism and Motherhood', History Workshop No. 5 (Spring 1998): p9-85; Anne-Emanuelle Birn, 'Skirting the Issue: Women and International Health in Historical Perspective', American Journal of Public Health, 89, no. 3 (March 1999): 399-407; and Susan Pedersen, 'The Maternalist Moment in British Colonial Policy: The Controversy over 'Child Slavery' in Hong Kong 1917-1941,' Past \& Present, no. 171 (2001): 161-202.

${ }^{51}$ Takeuchi-Demirci, Contraceptive Diplomacy, 56, 60.

${ }^{52}$ Sarah Hodges, Contraception, Colonialism and Commerce: Birth Control in South India, 1920-1940 (Routledge, 2008$), 13$. Takeuchi-Demirci, Contraceptive Diplomacy, 56.

${ }^{53}$ Takeuchi-Demirci, Contraceptive Diplomacy, 147.

${ }^{54}$ To obtain these figures, I entered each of the 557 articles published from 1952-1962 (not including book reviews) into a spreadsheet and coded them based on the relevant themes that were raised by the article. If an article raised more than one of these themes, I marked it under multiple categories. The totals above thus indicate the total number of mentions, rather than the total number of articles. Several other themes (refugees, migration ... etc) also appeared, but were not significant enough to be included in the chart.

${ }^{55}$ 'The World's Population', ATW, vol. 1, 1952/01, (B6, DHB Papers, SSC), 2.

${ }^{56}$ 'Penang', $A T W$, vol. 105, 1962/05, (B7, DHB Papers, SSC), 3.
} 
Many articles discussing the benefits to the family specifically stressed the issue of women's health and well-being (71\% under Brush and 50\% under Jackson), focusing on the physical and mental burden of childbearing and the improved maternal health outcomes linked to child spacing. A multitude of articles discussed the widespread practice of illegal, unsafe 'kitchen abortions,' undertaken by women facing unwanted pregnancies, which could lead to sepsis or other serious complications. ${ }^{57}$ As evident in Figure 4, a significant number of articles also continued to cover developments in infertility research, suggesting a vision of family planning that was not reducible entirely to population limitation.

\section{Most frequently mentioned themes under Brush}

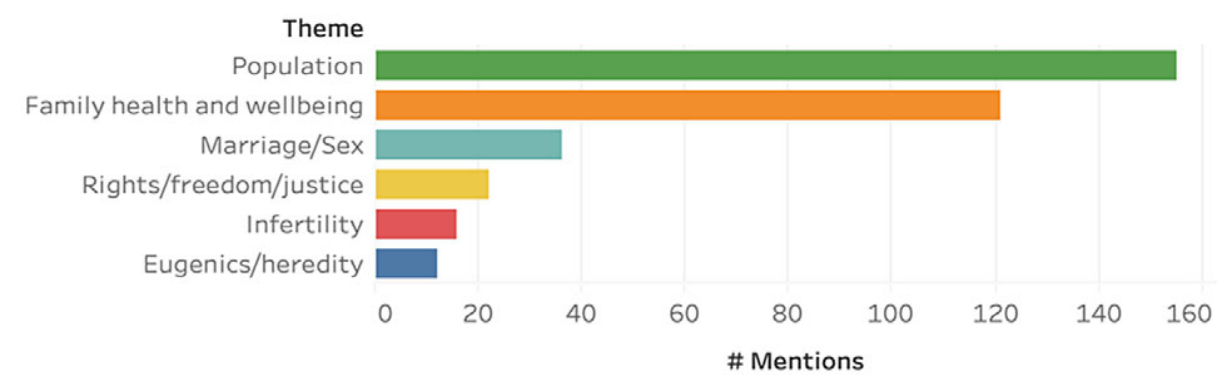

Most frequently mentioned themes under Jackson

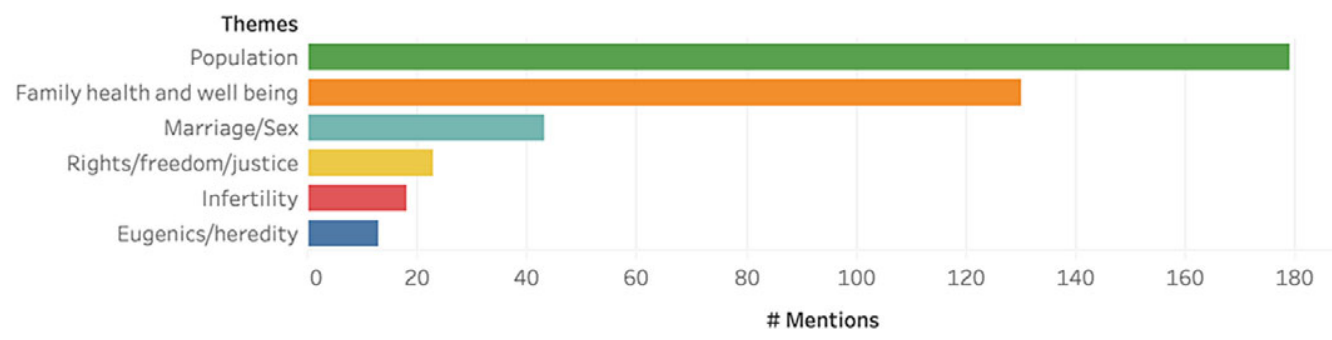

Figure 4. Most frequently mentioned themes under Brush and Jackson.

As scholars have illustrated, some IPPF advocates used the language of family health and wellbeing as a way to mask underlying eugenic or population control agendas; Blacker, for example, described this as a strategy of 'crypto-eugenics. ${ }^{58}$ Indeed, although Brush noted that eugenics had become something of a 'touchy' subject following the Second World War, coverage in the paper continued to discuss 'genetic degeneration,' often under the scope of 'hereditary counselling. ${ }^{59}$ But Brush's papers illustrate that the imperative for attention to family welfare also came from member associations more firmly rooted in medical and social work traditions. Letters from local advocates around the world repeatedly called for 'more emphasis in the bulletin on family health and less on over-population. ${ }^{60}$ Fieldworker reports also frequently noted resistance from local associations and family planning workers to the population focus increasingly pushed in the political and international realm. Some advocates - from Africa to Asia to Latin America - argued that

\footnotetext{
${ }^{57 ،}$ France', ATW, vol., 1956/04, (B6, DHB Papers, SSC), 1.

${ }^{58}$ Connelly, Fatal Misconception, 163.

${ }^{59 `}$ Eugenics', ATW, vol. 23, 1954/03, (B6, DHB Papers, SSC), 4. 'New Zealand', ATW, vol. 21, 1954/01, (B6, DHB Papers, SSC), 4. 'Heredity Counselling', ATW, vol. 25, 1954/05, (B6, DHB Papers, SSC), 1. Abraham Stone, 'Sterilization, ATW, vol. 33, 1955/03, (B6, DHB Papers, SSC), 2.

${ }^{60}$ 'Extracts from Minutes of the British Advisory Committee Acting as the Bulletin Advisory Committee', 1956-1959, (F11, B6, DHB Papers, SSC), 12. See also 'Ippf Bulletin', 1959/11/01, (F11, B6, DHB Papers, SSC), 1. [Dorothy Brush] to Elise [Ottesen-Jensen], 'Letter', 1959/06/03. (F 15, B2, DHB Papers, SSC), 1.
} 
their countries did not have a population problem; others, that it was a question of unequal distribution rather than family size per se. ${ }^{61}$ Many more saw the population question as simply secondary to their primary focus on health and welfare. Dr. Fahrettin Kenim Gokay of Turkey, for example, did not believe there was a population problem in his country but stressed the need for voluntary parenthood for 'the welfare of the individual family. ${ }^{\prime 2}$ Doctor Percy Boland wrote from Bolivia that regardless of population rates, from 'a physician's point of view' there was a need for family planning in his country, where mothers bore an average of twelve or more children and maternal mortality rates were high. ${ }^{63}$

As scholars of twentieth century maternalist movements have noted, if this language of family health and well-being could draw attention to women's challenges, it could also reinforce conservative ideas of the family by naturalizing the nuclear family model and women's primary role as reproducer. ${ }^{64}$ Indeed, Sandra Whitworth argues that the IPPF's promotion of a depoliticized, heterosexual, two child nuclear family in its early years drew the focus of the movement away from the more disruptive language of the early birth control movement. ${ }^{65}$ While this is certainly evident in much of the coverage of $A T W$, a number of articles discussing sex and marriage did take a more liberal stance. An article on 'The Status of Women' in West Germany, for example, lamented the fact that 'a married woman returning from work in the evening may have to forget 20 years of social progress as she enters the house,' although it noted that this was changing as 'a wife is becoming more of a partner and less of a servant. ${ }^{66}$ In a book review, Jackson portrayed the argument that 'a woman should completely own and control her own body whether within or without the matrimonial bond' as a matter of common sense. ${ }^{67}$ Discussions of sex education within the IPPF could also be exceptionally bold for their time. The paper stressed the need to discuss sex 'simply, clearly, without self-consciousness. ${ }^{68}$ At one conference, Professor Tadeusz Bilikiewicz of Poland (commenting on the sex life of ageing populations) reportedly claimed that: 'our sexual organs, like our brains, would function longer if kept in proper use!' ${ }^{69}$ Indeed, $A T W$ was attacked at the time by the Vatican newspaper Osservatore Romano in November 1959 on the grounds that it promoted 'propagandistic licentiousness,' offended religion, and was a 'foreign importation. ${ }^{70}$

$A T W$ also continued to tap into feminist discourses, praising advances in women's rights around the world, including the new Hindu Code in India in 1956, the rising feminist movement in Egypt, and political support for the emancipation of women in Tunisia. ${ }^{71}$ Explicit statements connecting family planning to women's rights in ATW also came from around the world. Dr. Lin Yutang, vice-chancellor of Nanyang University in Singapore, for example, was quoted in ATW as saying that: '[a]ll emancipation of women is a mask and an illusion unless they are given the knowledge whereby they can plan their families wisely. ${ }^{72}$ Funmilayo-Ransome Kuti, founder of the Nigerian Women's Union, reportedly regarded family planning as 'a basic right of

\footnotetext{
${ }^{61}$ For examples of the first argument, see: Mrs. Morain, 'Field Report for Mrs Brush by Mrs Morain, Africa', 1959/01-02. (F1, B8, DHB Papers, SSC), 2.; Family Planning Association of Pakistan, 'Report on the First Indian Ocean Regional Conference of the International Planned Parenthood Federation', Lahore, 1962. (F10, B6, DHB Papers, SSC), 47.; Margaret F. Roots, 'Report to Pathfinder Fund: Burma', 1959/12. (F20, B7, DHB Papers, SSC), 1. For the second, see 'Perkumpulan (Association) "Keluarga Berentjana” (Planned Parenthood)', 1957/12/23. (F10, B10, DHB Papers, SSC), 1-2.

${ }^{62 ‘}$ Turkey', $A T W$, vol. 13, 1953/03, (B6, DHB Papers, SSC), 4.

${ }^{63}$ 'Bolivia', ATW, vol. 39, 1955/11, (B6, DHB Papers, SSC), 2.

${ }^{64}$ Möller et. Al, 'Gendering Twentieth-Century Humanitarianism', 26.

${ }^{65}$ Whitworth, Feminism and International Relations: 80-118.

${ }^{66}$ 'The Status of Women', ATW, vol. 76, 1959/06, (B7, DHB Papers, SSC), 2-3.

${ }^{67}$ 'Reviews', $A T W$, vol. 106, 1962/06, (B7, DHB Papers, SSC), 4.

${ }^{68 ‘}$ Reviews', $A T W$, vol. 61, 1958/01, (B7, DHB Papers, SSC), 4.

${ }^{69}$ Barbara Cadbury, 'Warsaw', ATW, vol. 107, 1962/09, (B7, DHB Papers, SSC), 3.

${ }^{70}$ L.N.J., 'Tut-Tut!' $A T W$, vol. 72, 1959/02, (B7, DHB Papers, SSC), 2.

${ }^{71}$ 'India', $A T W$, vol. 49, 1956/11, (B6, DHB Papers, SSC), 2. 'Egypt', ATW, vol. 70, 1958/12, (B7, DHB Papers, SSC), 6. 'Tunisia', ATW, vol. 95, 1961/05, (B7, DHB Papers, SSC), 1.

72‘Singapore’, $A T W$, vol. 33, 1955/03, (B6, DHB Papers, SSC), 3.
} 
Nigerian women who bear a heavy economic burden and take full responsibility for the care of their children. ${ }^{73}$ A group of Eastern European doctors at an IPPF conference in 1962 were apparently particularly adamant in stating that 'birth control is both an instrument of women's emancipation from fear and impossible of acceptance without that emancipation. ${ }^{74}$ If this language had disappeared in certain spheres of the movement in the mid-twentieth century, ATW suggests it continued to hold appeal amongst the broader family planning community.

The IPPF and local associations also tapped into an emerging discourse of human rights and child rights. As Caroline Rusterholz points out, already by 1953 the IPPF had begun to recognize contraception as 'a fundamental human right. ${ }^{75}$ The argument that children had a 'right' to be purposefully brought into being was also an oft-repeated mantra in the paper. Again, this seems to have drawn at least in part on the language used by local member associations. ATW noted, for example, a poster on the wall of the All India Institute of Hygiene and Public Health claiming that adults had 'the right for their own sake to separate the twofold functions of the sexual union,' and that 'children have an even better right to be brought into being... only if and when their births are whole-heartedly desired and conscientiously provided for. ${ }^{.76}$ The FPA of Ceylon similarly argued in its annual report that planned parenthood was, above all, 'a humanitarian programme serving individual people,' noting that 'doctors, sociologists, philosophers, humanitarians, and religious leaders agree that it is the basic right of parents to have babies only when they want them. A child's first birth right is to be wanted. ${ }^{\text {'7 }}$

$A T W$ merged this language of rights with the traditional emotional repertoire of maternalist humanitarianism, making the case for family planning on the basis of compassion, empathy, and love as much, if not more so, than through an appeal to a rational discourse of population management. While the paper regularly published population statistics at the beginning of its articles on local countries, Brush published an op-ed in the second volume of the paper reminding readers that 'The Masses are People,' made up of individuals who should not be regarded as an abstract entity. ${ }^{78}$ The editors of $A T W$ also spoke of the 'desperate letters from hard-pressed parents' they received and occasionally published them in the paper. ${ }^{79}$ One, from a 'Nicaraguan mother,' read: 'I am badly in need of your help. I am thirty-two years and have six children under 12. My privation is very great. My husband is but a humble carpenter, wages low. Please assist me! ${ }^{80}$ A letter from a man in India noted that he and his wife had an 'undesired son' and were seeking the ' $100 \%$ safest methods of birth control,' noting that abstinence was no remedy 'for a young couple like us who love each other most heartily. ${ }^{81}$ The paper also covered the emotional content of IPPF conferences as much as the scientific findings. In a report on an IPPF conference in 1953, for example, $A T W$ reported how Japanese nurse Chimo Mashima broke down into tears recounting the desperate situation of women facing multiple abortions; attendees left 'with the plea ringing in their hearts. ${ }^{82}$ At a regional conference in Puerto Rico in 1954, a 'Spanish girl' sang 'soft songs of love and suffering' that 'echoed the unspoken message of our movement - human love should not be penalized by human suffering. ${ }^{, 83}$ Indeed, Brush claimed that IPPF conferences could take on 'a

\footnotetext{
73‘Africa', ATW, vol. 77, 1959/09, (B7, DHB Papers, SSC), 3.

${ }^{74}$ Barbara Cadbury, 'Warsaw', ibid., 2.

${ }^{75}$ Rusterholz, 'English Doctors, Contraception and Family Planning', 159.

${ }^{76}$ 'India', $A T W$, vol. 42, 1956/02, (B6, DHB Papers, SSC), 4. See also: 'War and Peace', ATW, vol. 60, 1957/12, (B7, DHB Papers, SSC), 7. 'Italy', ATW, vol. 93, 1961/03, (B7, DHB Papers, SSC), 3.

${ }^{77}$ The Family Planning Association of Ceylon, 'Eleventh Annual Report 1963-1964', 1964. (F3, B8, DHB Papers, SSC), 39.

${ }^{78}$ Dorothy Brush, 'The Masses are People', ATW, vol. 2, 1952/02, (B6, DHB Papers, SSC), 1.

${ }^{79}$ 'Need', $A T W$, vol. 4, 1952/04, (B6, DHB Papers, SSC), 3.

${ }^{80}$ Ibid, 3.

${ }^{81}$ Hardyal Singh Grewal to PPFA, 'Letter', 1953/11/30. (F11, B6, DHB Papers, SSC), 1. Brush would generally respond to these letters by directing the writers to their nearest local family planning association.

${ }^{82}$ 'The Conference', ATW, vol. 18, 1953/10, (B6, DHB Papers, SSC), 4.

${ }^{83}$ 'Puerto Rico Conference', ATW, vol. 36, 1955/06, (B6, DHB Papers, SSC), 2.
} 
truly spiritual atmosphere,' due to the passion and emotional draw of the family planning cause. ${ }^{84}$

Scholarship on humanitarianism has stressed the power of mobilizing empathy; as Wilson and Brown note: '[a]ffect binds us together as much as laws and political institutions. ${ }^{85}$ Ilaria Scaglia argues that this mobilization of emotion was essential to many internationalist projects of the twentieth century, which sought to build 'emotional communities' bound together by shared feeling and a common emotional stylistics as much as through more formal mechanisms. ${ }^{86}$ Indeed, Sanger attributed ATW's success primarily to the warmth of Brush as editor, 'whose love for this work pulsates throughout each issue. ${ }^{87}$ Sanger, Brush, and others also lamented the somewhat less emotive approach taken by Jackson after he took over the paper in 1957. In an editorial in 1960, for example, Jackson argued that while on the family level the movement was 'primarily a matter of the heart,' on the global level it was 'very much a matter of the head, for when man is trying to prescribe for the betterment of humanity he must use his reason. ${ }^{\text {'8 }}$ In spite of his personal proclivities, however, the paper's coverage of the movement's female leaders continued to illustrate the blending of heart and head at the global level. Swedish advocate Elise Ottesen-Jensen, who took over the presidency of the IPPF in 1959, for example, continually reminded people that "statistics" referred to living human beings who could rejoice and suffer. 89

$A T W$ also painted a portrait of a global family planning movement that continued to be dominated by women's work at its core (see Figure 5). The various presidents of the organization received much of this attention: Sanger purportedly inspired large crowds around the world and admirers marveled at Rama Rau's ability to 'do all she does and yet remain so serene and poised. ${ }^{90}$ Ottesen-Jensen was described as a 'human dynamo' with 'boundless energy,' and even as 'something of a prophet, who speaks this gospel [of family planning] in six foreign tongues.' 91 But local birth control pioneers were also regularly highlighted in $A T W$ and the reports of international fieldworkers. There was 'the indefatigable Dr. [Siva] Chinnatamby' in Ceylon; Dr. Hameda Malik, the 'Mother of Family Planning in Dacca;' 'dynamo of energy' Dr. Celestina Zalduondo in Puerto Rico; and 'cheerful, enthusiastic Dr. Lotte Fink,' who escaped Nazi Germany for Australia. ${ }^{92}$ Perhaps the most inspiring tale was that of Dr. Hoon Pierra Vejjabul, who left Thailand for Paris as a young woman against her parents' wishes, washing dishes in hotels to pay for medical school. Upon returning to Bangkok, she advocated for birth control access while also running an institute that housed forty abandoned children she had legally adopted. $^{93}$

\footnotetext{
${ }^{84}$ 'Birth of International Planned Parenthood Federation', ATW, vol. 11, 1953/01, (B6, DHB Papers, SSC), 1.

${ }^{85}$ Wilson and Brown, 'Introduction', 21.

${ }^{86}$ Scaglia, The Emotions of Internationalism, 3.

${ }^{87}$ Margaret Sanger, 'Happy Birthday', ATW, vol. 21, 1954/01, (B6, DHB Papers, SSC), 1.

${ }^{88}$ L.N.J., 'The Object of the Exercise', $A T W$, vol. 87, 1960/09, (B7, DHB Papers, SSC), 2.

${ }^{89}$ 'IPPF President on BBC', ATW, vol. 86, 1960/06, (B7, DHB Papers, SSC), 5. See also: Elise Ottesen-Jensen, 'The President's Message', $A T W$, vol. 91, 1961/01, (B7, DHB Papers, SSC), 1.

${ }^{90}$ 'Margaret Sanger', ATW, vol. 12, 1953/02, (B6, DHB Papers, SSC), 2. 'Bombay Conference', ATW, vol. 13, 1953/03, (B6, DHB Papers, SSC), 2.

${ }^{91}$ 'Sweden', $A T W$, vol. 3, 1952/03, (B6, DHB Papers, SSC), 2. 'Poland', ATW, vol. 82, 1960/02, (B7, DHB Papers, SSC), 3. Barbara Cadbury, 'Conference in the Sun', ATW, vol. 96, 1961/06, (B7, DHB Papers, SSC), 2.

${ }^{92 ‘}$ Ceylon', ATW, vol. 90, 1960/12, (B7, DHB Papers, SSC), 2; Margaret F. Roots to Mr. Kabir, 'Letter', 1959/05/05. (F20, B7, DHB Papers, SSC), 1; Sarah [Gamble], "Letter to Dorothy," 1960/02/11, (F13, B8, DHB Papers, SSC), 1; 'Bombay Conference', $A T W$, vol. 13, 1953/03, (B6, DHB Papers, SSC), 2.

${ }^{93}$ 'Thailand', $A T W$ vol. 4, 1952/04, (B6, DHB Papers, SSC), 1.
} 


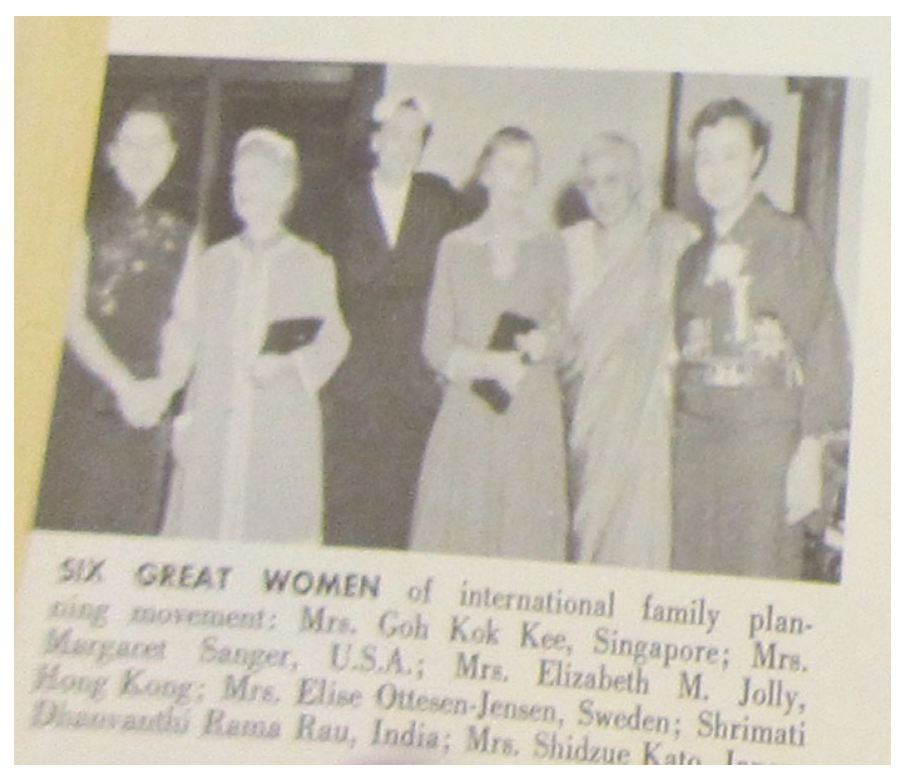

Figure 5. 'Six Great Women of international family planning'. Listed: Mrs. Goh Kok Kee, Singapore; Mrs. Margaret Sanger, U.S.A.; Mrs. Elizabeth M. Jolly, Hong Kong; Mrs. Elise Ottesen-Jensen, Sweden; Shrimati Dhanvanthi Rama Rau, India; Mrs. Shidzue Kato, Japan. ${ }^{94}$

Through these descriptions, ATW drew on a 'narrative of heroics' common to humanitarian propaganda. ${ }^{95}$ These narratives have been rightly critiqued for their tendency to gloss over the more complex personal biographies of individuals: for some of the women in family planning, this included connections to the eugenics movement. But the emphasis on these women in IPPF records also reminds us that, if conferences in Rome and board meetings in New York on the subject of population had been taken over by men after the Second World War, women continued to feature heavily in the family planning movement in other spaces. As with maternalist movements more broadly in this period, this included a disproportionate number of white European and American women abroad. ${ }^{96}$ Some had missionary backgrounds, such as Mrs. H.B. Amstutz, wife of the Methodist Bishop of Southeast Asia, who addressed organizations in the region on the subject of family planning. ${ }^{97}$ Others, such as Barbara Cadbury, who sent in materials and occasionally wrote for $A T W$, represented a new brand of socially active wives of United Nations bureaucrats. $^{98}$ But these international advocates were not engaged directly in delivering contraceptive services, a domain dominated by local doctors, nurses, and social workers, a majority of whom were women. ${ }^{99}$ Most local organizations also relied on a veritable army of (mostly female) volunteers, who hung posters, contacted patients, filed records, and reached out to potential members. They organized fund-raising campaigns: tea parties, dances, lectures, Christmas cards, raffles, and thrift shops. ${ }^{100}$ As ATW noted: '[o]f the devoted field workers in family planning, we hear too little. Their

\footnotetext{
${ }^{94} A T W$, vol. 40, 1955/12, (B6, DHB Papers, SSC).

${ }^{95}$ Bernard Taithe, 'Humanitarian Masculinity: Desire, Character and Heroics, 1876-2018', in Moller et al. Gendering Humanitarianism in the $20^{\text {th }}$ century, 55.

${ }^{96}$ See Allman, 'Making Mothers'; Davin, 'Imperialism and Motherhood'; Pederson, 'The Maternalist Moment in British Colonial Policy.'

97'Towards Personal Merdeka', ATW, vol. 55, 1957/05, (B7, DHB Papers, SSC), 3.

${ }^{98 ' M r}$. and Mrs. George Cadbury', ATW, vol. 89, 1960/11, (B7, DHB Papers, SSC), 4.

${ }^{99}$ Bourbonnais, 'Population Control, Family Planning, and Maternal Health Networks', 349-50.

${ }^{100}$ See for example 'U.S.A.' ATW, vol. 14, 1953/04, (F12, B6, DHB Papers, SSC), 4. 'New Publications', ATW, vol. 57, 1957/ 09, (B7, DHB Papers, SSC), 4. Asociacion Mexicana Pro-Bienestar de la Familia, 'Bulletin No. 1', 1960/01. (F13, B8, DHB Papers, SSC), 2. Asociacion Mexicana Pro-Bienestar de la Familia, 'Annual Report', 1960/02/29. (F13, B8, DHB Papers, SSC), 5. Family Planning Association of China, 'Monthly Activity Report', 1964/04. (F4, B8, DHB Papers, SSC), 1. 'U.S.A.', ATW, vol. 14, 1953/04, (F12, B6, DHB Papers, SSC), 4.
} 
reports - like their lives - are concentrated on the plight of those they serve. Only in letters do we ever glimpse personal hardships and then tossed off with humor. ${ }^{101}$ The paper tried to rectify this by covering even the most seemingly mundane aspects of activism, illustrating the daily labour involved in constructing both local and international movements.

The appeal of this message is evident in excerpts from letters written to Brush in the early years of the paper. Dr. Marui Rouhunkoski of Finland, for example, wrote that the newsletter meant a great deal 'to people like myself who work in comparative isolation. Its regular arrival gives us contact with others who have the same interests and we no longer feel alone. ${ }^{102}$ Although the majority of these letters came from the USA, UK, and India, letters from Malaysia, Chile, Italy, Haiti, France, Kenya, Pretoria, Belgium, Canada, Japan, Switzerland, Puerto Rico, and Australia suggest the newsletter's vision held broader appeal. ${ }^{103}$ Brush's correspondence also illustrates the role of gift-giving and favours in cementing ties among advocates. Brush received dresses and paintings from Italian advocate Vittoria Olivetti and added two hearts to her charm bracelet to represent Olivetti's twins, calling them her 'adopted grandchildren.' ${ }^{104}$ She sent a raincoat to Purai na Bangxang of Thailand who in turn sent her jewels, silk, and a sapphire, while appealing to Brush to help her son settle in the United States. ${ }^{105}$ Brush attended Singaporean Goh Kok Kee's daughter's commencement at Oberlin college and called Tze-kuan Shu Khan of Taiwan her 'adopted daughter.' ${ }^{\text {'106 }}$ In doing so, these actors illustrated how international relationships were cemented through affective ties, gift giving, and regular correspondence in addition to formal associational memberships and conferences. Indeed, as Sasson argues, the global idea of humanity 'could be produced in the most local and intimate spheres of everyday life, as much as it could take place in national and international spaces. ${ }^{\prime 107}$

By tapping into narratives of empathy and suffering and mobilizing local women's volunteer work, mid-twentieth century family planners continued to locate their work within a tradition of maternalist humanitarianism, although one which was compatible with feminist principles and a broader concept of human rights. In Mary Ladd-Taylor's classification, family planners might fit best within a tradition of 'progressive' maternalists committed to more liberal causes rather than 'sentimental' maternalists with traditional or religious leanings. ${ }^{108}$ Still, in some places, these points of connection and crossovers in personnel appear to have fueled direct cooperation even with more traditional humanitarian organizations that distanced themselves from the cause on the international stage. Local chapters of the Red Cross, for example, reportedly supported family planning work in Poland, South Africa, and El Salvador, and the family planning clinic in Southern Rhodesia operated out of the Red Cross Centre in Harari Township. ${ }^{109}$ In Nairobi, the local FPA screened films at the Young Women's Christian Association (YWCA) and held a booth at World Health Organization (WHO) conferences. ${ }^{110}$ Indeed, although the WHO

\footnotetext{
${ }^{101 ‘}$ Field Day', $A T W$, vol. 48, 1956/10, (F12, B6, DHB Papers, SSC), 1.

102'The Conference', $A T W$, vol. 18, 1953/10, (B6, DHB Papers, SSC), 4.

${ }^{103}$ See for example: 'Expressions of Opinion About the Bulletin', 195/05/17. (F11, B6, DHB Papers, SSC). 'Expressions of Opinion About the Bulletin', 1952/02/25. (F11, B6, DHB Papers, SSC).

${ }^{104}$ [Dorothy Brush] to Vittoria [Olivetti], 'Letter', 1958/02/26. (F14, B2, DHB Papers, SSC), 1., Maria Luisa de Marchi to Dr. Clarence J. Gamble, 'Letter', 1959/04/06. (F23, B1, DHB Papers, SSC). [Dorothy Brush] to Rufus [Day], 'Letter', 1962/01/18. (F17, B1, DHB Papers, SSC), 1.

${ }^{105}$ [Dorothy Brush] to Purai, 'Letter', 1960/11/18. (F10, B1, DHB Papers, SSC), 1.

${ }^{106}$ [Dorothy Brush] to [Tze-kuan Shu Khan], 'Letter', 1959/05/12. (F6, B2, DHB Papers, SSC), 1. [Dorothy H. Brush] to Mrs. Lloyd Morain, “Letter," 1959/05/? 1.

${ }^{107}$ Hilton et al, 'History and Humanitarianism', 28.

${ }^{108}$ Ladd-Taylor, 'Toward Defining Maternalism in U.S. History'.

${ }^{109}$ International Planned Parenthood Federation, 'Fourth Report', London, England, 1957/01/01-1959/05/31. (F10, B6, DHB Papers, SSC), 89, 93; Edris Rice-Wray, 'Report on Trip to El Salvador, Honduras, Costa Rica and Guatemala in the Interest of Planned Parenthood', 1960/04. (F21, B7, DHB Papers, SSC), 2; Edith M. Gates, 'News from the Rhodesias', 1959/11. (F19, B7, DHB Papers, SSC), 1.

${ }^{110}$ Edith M. Gates, Special Visit to Nairobi, Kenya, 1959/08/24-09/03, (F19, B7, DHB Papers, SSC), 1.
} 
did not openly support family planning until the late 1960s out of concern for opposition from Roman Catholic countries, these records suggest that some local representatives collaborated unofficially. ${ }^{111}$

Brush's papers thus illustrate how personal bonds and a language of maternalist humanitarianism could cut through some of the intense political divisions operating on the international stage during this period. Indeed, if prominent advocates and philanthropists during this period had become keen political strategists, IPPF fieldworkers, and local advocates alike often saw themselves as operating outside of the realm of politics, mobilizing a language of global humanity and an ideal of political neutrality to affirm their distance from the geopolitical conflicts dominant in other spaces. As discussed in the next section, this discourse allowed $A T W$ to present a unique vision of global struggle that challenged traditional hierarchies in some areas. This discourse, however, was undermined by colonialist mentalities and concepts of racial superiority that continued to shape the practice of international movement building, as well as the very real political conflicts that shaped their work in spite of - or perhaps precisely because of - their proclaimed political neutrality.

\section{Estranged daughters and the impossible ideal of political neutrality: tensions of the maternalist humanitarianism project}

If the tradition of humanitarianism has provided a powerful international mobilizing force in the past century, critical studies have pointed to a series of contradictions underlying its core principles of compassion, global humanity, and political neutrality. As Michael Barnett notes, compassion can easily transform into paternalism, with self-appointed caretakers justifying the violation of an individual's liberty for the sake of their own perceived welfare and interests. ${ }^{112}$ Humanitarianism also has deep ties to colonialism and imperialism: discourses of humanitarian need have been mobilized to justify imperial interventions, while humanitarian organizations have historically cooperated with European colonial states, providing the daily labour undergirding the paternalistic 'civilizing mission.' Indeed, Susan Pederson describes British women's maternal and child welfare work abroad as a form of 'maternalist imperialism,' serving as 'the feminine component of the ideology of trusteeship. ${ }^{\prime 13}$ Narratives of 'global humanity' may also continue to reinforce Western-centric assumptions that unite the world primarily around European or American models. ${ }^{114}$ Efforts to portray humanitarianism as an ethical or technical project can further fail to recognize that any intervention into the lives of others is inherently a political project, with political implications. The humanitarian narrative can even stymie the articulation of political solutions, by channeling energy towards 'emotional responses to victims' rather than broader movements for political change. ${ }^{115}$

While these critiques have gained more visibility within scholarship in the past few decades, Brush's papers remind us that anti-imperialists were already making many of these points in the immediate post-war period, and humanitarians were already attempting to respond to them. As Brush wrote in her coverage leading up to the Bombay conference in 1952: 'We of the West are going to the conference to offer our "know-how" but also to learn. We are not going to impose it....The West needs to learn as well as the East.' She quoted Indian philosopher Sir Sarvepalli Radhakrishnan as saying: 'None of us has been appointed to educate humanity.' 116 Brush echoed this sentiment in a fieldwork report from the late 1950s, noting that: '[p]robably due to the rise of

\footnotetext{
${ }^{111}$ On official WHO policy, see Bashford, Global Population, 20.

${ }^{112}$ Barnett, Empire of Humanity, 34.

${ }^{113}$ Pedersen, 'The Maternalist Moment in British Colonial Policy', 202. See also Allman, 'Making Mothers'; Davin, 'Imperialism and Motherhood.'

${ }^{114}$ Barnett, Empire of Humanity, 68.

${ }^{115}$ Tickten, 'International Humanitarianism', 281. See also Wilson and Brown, 'Introduction', 8, Suski, 'Children, Suffering, and the Humanitarian Appeal', 217.

${ }^{116}$ Dorothy Brush, 'Keynote', ATW, vol. 6, 1952/06, (B6, DHB Papers, SSC), 1.
} 
racial nationalism, the Lady Bountiful approach is obsolete... People no longer expect us to organize ... they want to do it themselves.' Local leaders, she noted, were 'high calibre, well-educated,' and mostly seeking access to materials and shared experiences, rather than leadership. ${ }^{117}$ In a letter to a professor in Ghana, she noted that ' $\mathrm{t}$ ]imes have changed entirely and it is a very good change. The International Planned Parenthood Federation does not impose its ideas on anyone... As a rule we do not go into any country except on invitation or where we have reasons to believe that different individuals would welcome us. ${ }^{118}$ Other IPPF members similarly argued against aggressive international intervention or universalist approaches. Dr. Edris Rice-Wray, an American based in Mexico in the 1950s, for example, critiqued those who might think that 'whatever was done in the United States or other parts of the world could be picked up as a package and repeated here... unless we direct our program in accordance with the needs of the people and their particular desires, and what they think is important, we fail before we start.' ${ }^{\text {'19 }}$

In fact, $A T W$ questioned whether the USA, or the West more broadly, really had much guidance to offer in the field of family planning. Asian countries were generally portrayed as more advanced in this realm, due to the early endorsement of family planning and its incorporation into government health services, starting with India in $1952 .{ }^{120}$ Governments in Ceylon (Sri Lanka) and Pakistan followed suit in the early 1960s, meeting the approval of the paper. As Brush noted: 'The most exciting change for the future of planned parenthood is the emergence of brilliant leadership in most of the Asiatic countries.' 121 Egypt also received 'resounding "Bravos" from all over the world' for endorsing birth control in 1956 and financing the creation of family planning clinics. ${ }^{122}$ Several other colonies and newly independent countries were further commended either for the leadership taken by their governments (as in Barbados, Mauritius, and Puerto Rico), or their particularly strong/innovative FPAs (as in Singapore, Hong Kong, South Africa, Kenya, and Jamaica).

The United States, in contrast, was chastised for its slow progress: although most large cities had private family planning clinics by 1952, only eight states incorporated it into public health services and contraceptives remained banned in the two 'backward states' of Massachusetts and Connecticut. ${ }^{123}$ This was deemed particularly problematic by the paper because of the 'startling population boom' in the USA following the Second World War. ${ }^{124}$ Indeed, in contrast to claims that there was a 'clear shift' in the movement in the 1950s to focus on the 'Third World' as the site of over-population and family planning intervention, $A T W$ continued to devote space to population growth in the USA and focused much of its coverage on 'backward' countries in Europe. ${ }^{125}$ Sometimes this categorization was based on sweeping generalizations about cultural patterns; after receiving a letter from one Greek reader, for example, Brush concluded that 'so far as we can discover, Greece knows nothing of family planning. ${ }^{126}$ Most of the countries in this category were considered backward, however, on the basis of hostile governments or the influence of the Catholic church. Italian and French governments, for example, continued to ban any publicity surrounding birth control in the 1950s, making even private, voluntary FPAs difficult to operate. ${ }^{127}$ The

\footnotetext{
${ }^{117}$ Brush, 'Report of the Hon. Adviser for Field Work Services', 1958? (F18, B7, DHB Papers, SSC), 2.

${ }^{118}$ Dorothy H. Brush to Professor St. Clair Drake, "Letter," 1959/05/23. (F1, B8, DHB Papers, SSC), 1.

${ }^{119}$ Edris to Mrs. Dorothy Brush, 'Letter', 1959/07/11. (F13, B8, DHB Papers, SSC), 1.

120'India', $A T W$, vol. 1, 1952/01, (B6, DHB Papers, SSC), 2.

${ }^{121}$ Dorothy Brush, 'Impressions of Asia', ATW, vol. 12, 1953/02, (B6, DHB Papers, SSC), 1.

${ }^{122 ‘}$ 'Egypt', $A T W$, vol. 41, 1956/01, (B6, DHB Papers, SSC), 2.

${ }^{123}$ 'India', ATW, vol. 8, 1952/10, (B6, DHB Papers, SSC), 1. 'United States', ATW, vol. 17, 1953/09, (B6, DHB Papers, SSC), 2.

124'US Survey', ATW, vol. 23, 1954/03, (B6, DHB Papers, SSC), 1-2.

${ }^{125}$ For the argument of a shift to the Third World, see Connelly, Fatal Misconception, 159.

${ }^{126 ‘ G r e e c e ', ~ A T W, ~ v o l . ~ 7, ~ 1952 / 09, ~(B 6, ~ D H B ~ P a p e r s, ~ S S C), ~} 3$.

${ }^{127}$ 'Italy', ibid., 2.
} 
only real leader among 'the West' appeared to be Sweden, which had, the paper noted, 'the most comprehensive population policy undertaken anywhere in the world. '128

This vision likely enhanced the appeal of the paper - and the IPPF more broadly - to family planning advocates around the world who saw their work recognized and placed on par, or even above, states with more international power in other spheres. Still, paternalist and racist colonial discourses continued to crop up in the coverage of $A T W$. Brush described voodoo religious ceremonies in Haiti as 'barbaric' and published articles on the 'primitive' beliefs in areas of Africa that clearly situated the populations of these countries - if not their family planning advocates - on a racist civilizational scale. ${ }^{129}$ At times, coverage of women's rights in the paper replicated the tropes of 'feminist Orientalism,' focusing on 'exotic' practices such as child marriage, polygamy, the veil, and purdah, and/or attributing gender inequality to 'medieval' local practices. ${ }^{130}$ The paper also downplayed the tensions surrounding decolonization, claiming for example that Ceylon achieved its independence from Britain 'with hardly a pinprick of exasperation on either side' and describ-

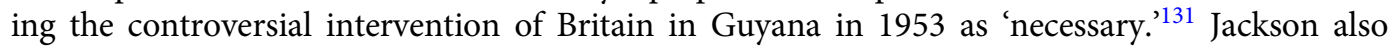
appeared less concerned with challenging Western claims to superiority than Brush. For example, responding to arguments that Western nations should not 'preach or impose birth control' on other countries but rather let them take the lead themselves, Jackson wrote in ATW: 'If this is true we must expect that, in many cases, little will be done.'132

Internal correspondence also illustrates the deeply rooted nature of racist attitudes and the tensions they could provoke between IPPF staff and local advocates in practice. Although these incidents were often elusively referred to as 'friction,' some local actors were frank in calling out the patronizing or racist attitudes of IPPF advisors. ${ }^{133}$ Goh Kok Kee, for example, wrote to Brush in the mid-1950s that one particular IPPF director for the Southeast Asia region held 'warped' attitudes towards Asian people and would do 'a great deal of harm to our cause' if not removed (he was). ${ }^{134}$ Several local actors - including Sylvia Fernando of Ceylon and Beth Jacobs of Jamaica also complained about statements made by C.P. Blacker which they saw as marginalizing their role in the movement or creating double standards between countries. Blacker responded defensively in a letter to Brush, complaining that 'I will be afraid soon to say anything at all!' ${ }^{135}$ While Brush generally defended local advocates in these affairs, she did so in ways that revealed her own deeply rooted sense of racial superiority. In one letter, for example, she described her efforts to seek solutions 'whenever I think my little brown brothers may get brushed off either accidentally or on purpose. ${ }^{\text {136 }}$ In spite of the claims to partnership and equality evident in $A T W$, Brush and other international fieldworkers clearly saw themselves as superior to and in a parental role above local advocates.

\footnotetext{
128'Sweden', ATW, vol. 3, 1952/03, (B6, DHB Papers, SSC), 3.

${ }^{129}$ 'Haiti', ATW, vol. 8, 1952/10, (B6, DHB Papers, SSC), 3. 'African Journey', ATW, vol. 26, 1954/06, (B6, DHB Papers, SSC), 2. 'Islands', $A T W$, vol. 38, 1955/10, (B6, DHB Papers, SSC), 3.

${ }^{130}$ On feminist orientalism, see Takeuchi-Demerci, Contraceptive Diplomacy, 57. For the use of 'medieval', see 'Haiti', ATW, vol. 8, 1952/10, (B6, DHB Papers, SSC), 3.

${ }^{131 ‘}$ 'Ceylon', $A T W$, vol. 29, 1954/11, (B6, DHB Papers, SSC), 1; 'British Guiana', $A T W$, vol. 30, 1954/12, (B6, DHB Papers, SSC), 4.

${ }^{132}$ 'People, Food and Power', ATW, vol. 54, 1957/04, (B7, DHB Papers, SSC), 3.

${ }^{133}$ For the use of 'friction', see C.P. Blacker to Dr. Clarence J. Gamble, 'Letter', 1958/05/14. (F12, B1, MS 23, DHB Papers, SSC), 3 .

${ }^{134}$ Mrs. K.K. Goh to Dorothy, 'Letter', 19[??]/07/23. (F16, B8, DHB Papers, SSC), 1.

${ }^{135}$ Pip (C.P.B.) to Dorothy, 'Letter', 1960/03/20. (Folder 12, Box 1, MS 23, Dorothy Hamilton Brush Papers, Sophia Smith Collection, Northampton, Mass.), 2.

${ }^{136}$ [Dorothy Brush] to Rufus [Day], 'Letter', 1962/01/18. (Folder 17, Box 1, MS 23, Dorothy Hamilton Brush Papers, Sophia Smith Collection, Northampton, Mass.), 1.
} 
The close bonds Brush formed with local advocates could also be stressed by political tensions. In 1959, for example, Brush found herself in a row with Tze-Kuan Shu Kan when the FPA of China (located in Taiwan) refused the IPPF's recommendation to change its name to the 'FPA of Nationalist China' to avoid confusion with Communist China. Writing to 'my dear adopted daughter,' Brush quickly added: 'Perhaps I shouldn't call you that anymore!' She expressed her shock that there had been no change in the name since their last meeting, and implored Tze-Kuan: 'for the sake of our friendship, won't you at least write and explain.'137 Tze-Kuan responded by noting that although 'Nationalist China' was used in foreign newspapers, the Taiwanese government had ruled that 'The Republic of China' or simply 'China' should be used. She held firm that the association would not change the name 'merely for facilitating our admission to IPPF' and felt that it was 'entirely unjustified for IPPF to take its present attitude toward our Association.' ${ }^{338}$ Although the two appear to have reconciled in later years, the dispute illustrates the very personal tensions that could form due to international fieldworkers' ignorance surrounding the finer points of local politics and sense of entitlement to determine the direction of the movement from abroad. ${ }^{139}$

The incident also reveals the fundamental difficulty - impossibility, even - of maintaining the humanitarian ideal of political neutrality in a politically complex world. This tension often came to a head in ATW and the IPPF's treatment of communist regimes, which vacillated between condemnation and attempts to form bridges across the Iron Curtain. Both Brush and Jackson were critical of early Marxist regimes that portrayed 'over-population' as a capitalist façade and family planning as a false panacea. Brush commented sarcastically in the paper on communists who sang 'their same old song of the heaven on earth at home' and Jackson argued that China's population growth illustrated that 'Marxism has so far failed to find the answer.' ${ }^{140}$ However, both covered communist regimes more favourably when they shifted course to promote family planning, as most did over the course of the 1950s-70s. For example, the paper praised the integration of contraception into health services in the Soviet Union, Hungary, and Czechoslovakia in the 1950s, and IPPF representatives visited these countries to provide advice and support. ${ }^{141}$ The IPPF also invited representatives of communist China to their conferences on the grounds that 'the population-control movement is international in scope and not subject to politics. ${ }^{\text {'142 }}$

The paper also wavered its treatment of more aggressive state-led population programs initiated in several countries in the 1960s. On the one hand, annual reports and conference speeches repeatedly stressed that the IPPF was 'strongly opposed to any method of family limitation being forced on people.' ${ }^{\prime 43}$ And yet, ATW praised state programs, particularly in Asia, for their 'leadership,' even as they turned to increasingly aggressive tactics such as mass sterilization or IUD insertion camps. To be sure, some IPPF stalwarts expressed concern from early on; according to an article in 1959, for example, Lady Rama Rau argued against the use of incentives for sterilization patients in India or the paying of extra fees for social workers who brought in volunteers. She warned that 'extraordinary precautions' had to be taken to avoid the exploitation of the poor in family planning programs. ${ }^{144}$ But the paper did not delve into the details of these tensions within the movement, or spell out clearly where the line should be drawn between coercion

\footnotetext{
${ }^{137}$ [Dorothy Brush] to [Tze-kuan Shu Kan], 'Letter', 1959/11/07. (F6, B2, MS 23, DHB Papers, SSC), 1.

${ }^{138}$ Family Planning Association of China to Mrs. Charles F. Brush, 'Letter', 1959/11/22. (F4, B8, DHB Papers, SSC), 1-2.

${ }^{139}$ On their continued engagement later, see: Dorothy Brush to Sai Poh (Mrs. Goh Kok Kee), 'Letter', 1960/11/21. (F26, B1, MS 23, DHB Papers, SSC), 1.

${ }^{140}$ 'The Listening Post', ATW, vol. 28, 1954/10, (B6, DHB Papers, SSC), 2. 'How Can they Stay Alive?' ATW, vol. 55, 1957/ 05, (B7, DHB Papers, SSC), 1.

${ }^{141}$ Abraham Stone, 'Dr. Stone in Russia', ATW, vol. 62, 1958/02, (B7, DHB Papers, SSC), 1. 'Dawn After Dark', ATW, vol. 47, 1956/09, (B6, DHB Papers, SSC), 1.

142‘'Tokyo Conference', ATW, vol. 40, 1955/12, (B6, DHB Papers, SSC), 8.

${ }^{143}$ 'IPPF Appeal', $A T W$, vol. 83, 1960/03, (B7, DHB Papers, SSC), 4.

${ }^{144}$ 'The Sterilization Issue', $A T W$, vol. 73, 1959/03, (B7, DHB Papers, SSC), 1.
} 
and free will. Sometimes, an article on the importance of free choice lay in the same issue as one about the need for aggressive sterilization programs, without ackowledgment of the inherent contradictions between these goals. As would become apparent in the following decades, political neutrality was not entirely compatible with the principles of care and rights at the core of the maternalist humanitarian tradition.

\section{Conclusion}

Over the course of the 1970s and 1980s, concerns over these coercive tactics and unethical practices in family planning programs around the world - including the use of incentives to entice birth control acceptors, sterilizations conducted without consent, and insufficient medical care for those suffering side effects - would gain increased visibility on the international stage and prompt a fracturing of the international family planning movement. At the United Nationshosted International Conference on Population and Development (ICPD) in Bucharest in 1974, leaders from the Global South challenged the underlying structures and basic theories of the population control establishment, openly charging aid agencies with neo-colonialism and arguing that 'development is the best contraceptive. ${ }^{145}$ Religious leaders and pro-natalist groups seized on these critiques, using the cooperation of international organizations like the IPPF with the one-child policy in China and mass sterilization campaigns in India to discredit the cause of family planning more broadly. ${ }^{146}$ An emerging international women's health movement in the 1990s critiqued both coercive population control and pronatalism, calling for a more comprehensive platform of 'reproductive rights,' including the right to have and not have children free of coercion and with adequate resources available to achieve optimum reproductive health. This concept was ultimately embodied in the 'Cairo platform,' signed by UN member countries at ICPD 1994 and subsequently embraced by the international community, incorporated into the core mission and principles of nearly every family planning/population organization and program within the following decade. ${ }^{147}$

Historians have been somewhat split on the impact of this moment: for Connelly, it is the moment when the population control agenda was finally defeated and the movement as a whole 'redeemed,' while others have pointed to the limits of the Cairo platform and the continuing influence of neo-Malthusian thought on population programs, regardless of the new language of reproductive rights. ${ }^{148}$ Popular debates have also continued to call for a more thorough reckoning with the legacy of eugenics on the movement, and in particular the connection between feminist activists and eugenics. These mobilizations have had tangible outcomes: Sanger's name has been removed from the Planned Parenthood Federation of America's Manhattan clinic, for example, and the British organization Marie Stopes International recently became 'MSI Reproductive Choices,' both efforts aimed at distancing the organizations from their founders' ties with the eugenics movement. ${ }^{149}$ Meanwhile, international anti-choice organizations such as Human Life International and the so-called 'Unholy Alliance' of conservative countries at the United

\footnotetext{
${ }^{145}$ Connelly, Fatal Misconception, 311-4.

${ }^{146}$ Ibid, 351-5.

${ }^{147}$ Connelly, Fatal Misconception, 360-9.

${ }^{148}$ For the first quote, see Ibid, xii; for the latter argument, see for example Carole McCann, 'Review of Fatal Misconception: The Struggle to Control World Population by Matthew Connelly; The Sterilization Movement and Global Fertility in the Twentieth Century by Ian Dowbiggin', The American Historical Review, 116, no. 3 (June 2011): 776.

${ }^{149}$ Elisha Fieldstadt, 'Planned Parenthood of Greater New York to remove late founder's name from center due to "racist legacy.” https://www.nbcnews.com/news/us-news/planned-parenthood-greater-new-york-remove-late-founder-s-name-n1234483. Liz Ford, 'Marie Stopes charity changes name in break with campaigner's view on eugenics', https://www.theguardian. com/global-development/2020/nov/17/marie-stopes-charity-changes-name-in-break-with-founders-view-on-eugenics.
} 
Nations continue to mobilize the legacy of coercion in the family planning movement as a means to stymie efforts to promote access to contraception and reproductive rights internationally. ${ }^{150}$

In light of the ceaselessly heated debates over the history of family planning at the highest levels of global politics, it would be easy to overlook the less straightforward legacy of the maternalist humanitarian tradition on the family planning movement. The deeply felt imperative to act, the emotional response to suffering, and the sense of the movement as women's work could challenge the dehumanization and instrumentalization of women's bodies inherent in the population control agenda. But it could also create its own problems. Politics cannot simply or easily be put aside to deal with suffering, and the line between solidarity and intervention can be razor thin. As Avishai Margalit points out: 'Caring may easily play out at the expense of respect for the other person's autonomy.' ${ }^{151}$ While these frictions are subtler than those caused by the blatantly coercive population control agenda, they are also more likely to last long past the advance of the reproductive rights paradigm, as international organizations continue to engage with humanitarian ideals and face the practical contradictions inherent in the ideal of political neutrality.

Understanding this movement in its full complexity also requires us to move past the most prominent advocates and most visible forms of international action, to explore in more detail the work of international community building by those mid-level actors whose work attracted little attention beyond their own organizations. The goal is not to recover 'unsung heroes' - as they often saw themselves - but rather to recognize the much broader network of actors and the much more intimate forms of daily labour that are required to build and sustain a movement, and that ultimately influence how it plays out in reality. The potential for liberation and exploitation inherent in this movement was a function of its complex ideological influences at the highest levels, but it was also a product of the interactions between the movement's 'workers' around the world. By paying attention to their forms of engagement and the tensions that shaped their work, we can create more nuanced understandings of the creation, consolidation, and fractures that shape international movements, and global history more broadly.

\footnotetext{
${ }^{150}$ Murphy, 'Technology, governmentality, and population control',69. Sonia Corrêa, 'Reproductive and Sexual Rights: International Trends from a Global South Perspective', International Encyclopedia of the Social \& Behavioral Sciences (Elsevier Ltd., 2015): 457-67.

${ }^{151}$ Quoted in Barnett, Empire of Humanity, 34.
} 